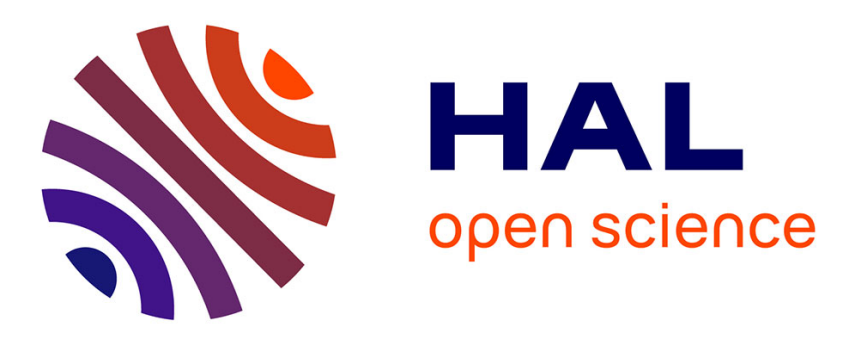

\title{
Kinetics of the oxidation of stainless steel in hot and concentrated nitric acid in the passive and transpassive domains
}

Elsa Tcharkhtchi-Gillard, Marie Benoit, P. Clavier, B. Gwinner, F. Miserque, Vincent Vivier

\section{To cite this version:}

Elsa Tcharkhtchi-Gillard, Marie Benoit, P. Clavier, B. Gwinner, F. Miserque, et al.. Kinetics of the oxidation of stainless steel in hot and concentrated nitric acid in the passive and transpassive domains. Corrosion Science, 2016, 107, pp.182-192. 10.1016/j.corsci.2016.02.031 . hal-01297900

\section{HAL Id: hal-01297900 https://hal.sorbonne-universite.fr/hal-01297900}

Submitted on 5 Apr 2016

HAL is a multi-disciplinary open access archive for the deposit and dissemination of scientific research documents, whether they are published or not. The documents may come from teaching and research institutions in France or abroad, or from public or private research centers.
L'archive ouverte pluridisciplinaire HAL, est destinée au dépôt et à la diffusion de documents scientifiques de niveau recherche, publiés ou non, émanant des établissements d'enseignement et de recherche français ou étrangers, des laboratoires publics ou privés. 


\title{
Kinetics of the oxidation of stainless steel in hot and concentrated nitric acid in the passive and transpassive domains
}

\section{E. Tcharkhtchi Gillard ${ }^{1,2}$; M. Benoit ${ }^{1}$; P. Clavier $^{1}$; B. Gwinner ${ }^{1, *}$; F. Miserque ${ }^{3}$; V.} Vivier $^{2}$

1 CEA, DEN, DANS, DPC, SCCME, Laboratoire d'Etude de la Corrosion Non Aqueuse, F-91191 Gif-sur-Yvette, France.

2 CNRS - UPMC, UMR 8235, Laboratoire Interfaces et Systèmes Electrochimiques, F75252 Paris 05, France.

3 CEA, DEN, DANS, DPC, SCCME, Laboratoire d'Etude de la Corrosion Aqueuse, F91191 Gif-sur-Yvette, France.

* Corresponding author. Tel./fax: +33 $1169 \quad 08$ 16 40 . E-mail address: benoit.gwinner@cea.fr

\begin{abstract}
Oxidation of $304 \mathrm{~L}$ stainless steel was studied in $4 \mathrm{~mol} / \mathrm{L}$ nitric acid solution at $100^{\circ} \mathrm{C}$ over a wide potential domain. For different potentials, long-term chronoamperometry experiments coupled with mass loss measurements were performed until steady-state was reached to characterize the corrosion kinetics of the passive and transpassive domains. With EIS and XPS measurements, the passive domain was characterized by the formation of a thin film, the thickness of which was potential dependent.
\end{abstract}

\section{Keywords:}

A. Stainless steel; B. Potentiostatic; B. XPS; C. Acid corrosion; C. Passive film; C. Transpassivity

\section{Introduction}


In France, reprocessing of spent nuclear fuel is based on the PUREX chemical process (Plutonium and Uranium Refining by EXtraction) [1]. The preliminary steps consist in the shearing of fuel clads, the dissolution of spent fuel in nitric acid, and the recovery of insoluble solids by clarification. Then the PUREX process uses an organic solvent (tributylphosphate) to extract uranium and plutonium, to recover fission products in nitric acid phase, to extract plutonium from the uranium/plutonium solution by reduction of plutonium, and to purify, concentrate and chemically transform uranium and plutonium. The products are plutonium which can be used with depleted uranium for MOX fuel manufacturing, and uranium enriched at the level of the spent fuel. As a consequence of the use of nitric acid to dissolve oxide spent fuel, various nitric media are met throughout the process. Nitric acid is at concentrations almost up to the azeotropic level $(14.4 \mathrm{~mol} / \mathrm{L})$ and at temperatures up to its boiling temperature $\left(120^{\circ} \mathrm{C}\right.$ for $\left.14.4 \mathrm{~mol} / \mathrm{L} \mathrm{HNO}_{3}\right)$. These nitric media, processed at pressures not higher than atmospheric, may be more or less renewed, depending on the equipment (e.g. fuel dissolver, fission product concentrators, acid recovery evaporators, fission-product storage tanks). In order to properly contain these very acidic and very oxidizing media, metallic materials have been chosen according to their corrosion limits, optimized and qualified before the building of the plants [2]. They are mainly very low carbon austenitic stainless steels (AISI 304L, 316L and $310 \mathrm{Nb}$ ) for the major part of the equipment; a special stainless steel with $4 \%$ silicon, for the fission product evaporators; zirconium, chosen for the construction of the most critical equipment in term of corrosion, such as fuel dissolvers and nitric acid recovery concentrators. It is therefore of great importance to have a precise knowledge of the corrosion mechanisms of these materials in nitric acid media.

Concerning SS (more specifically 304L), the corrosion potential is in the passive domain where SS oxidation corresponds to the formation of $\mathrm{Fe}(\mathrm{III}), \mathrm{Cr}(\mathrm{III})$ and $\mathrm{Ni}$ (II) [3]. The 
oxidation rate is low due to the existence of a metastable [4] chromium-rich-oxide layer at the surface [5-7]. In addition, any increase of nitric acid temperature or concentration can lead to an increase of the SS corrosion potential, which could thus be shifted into the transpassive domain, where corrosion is severe $[5,6,8]$. In this potential range, $\mathrm{Cr}$ is possibly oxidized to $\mathrm{Cr}(\mathrm{VI})$ that rapidly dissolves [3] and intergranular corrosion (IGC) is also observed [5, 6, 9]. IGC results from a preferential corrosion at grain boundaries, which generates triangular grooves at grain boundaries. The progression of these grooves inside the steel can induces grain dropping. Some authors proposed that this IGC morphology results from the existence of two different dissolution rates: a dissolution rate at the surface of the grains $V_{\mathrm{s}}$ and a dissolution rate at the grain boundaries $V_{\mathrm{gb}}[10$ 14]. Based on this phenomenology, a model shows that the total mass loss of the steel is thus ascribable to two contributions: steel oxidation / dissolution and grain dropping [13]. In addition to metal oxidation, nitric acid reduction occurs in a large potential range that partially superimposes the anodic domain of SS [2, 14]. The complex reduction phenomena of nitric acid have been widely studied and the reduction mechanisms on the surface of an inert electrode are now well established [15-23]. These mechanisms appear to depend mainly on the potential and on the concentration of the nitric acid. For a small over-potential a first autocatalytic process was shown firstly by Vetter [24-26]. The mechanism is based on the adsorption and reduction of $\mathrm{NO}_{2}$ (valence IV of nitrogen) to $\mathrm{NO}^{+}$or $\mathrm{HNO}_{2}$ (valence III of nitrogen). Then $\mathrm{NO}^{+} / \mathrm{HNO}_{2}$ can be oxidized by $\mathrm{HNO}_{3}$ (valence $\mathrm{V}$ of nitrogen) to form again $\mathrm{NO}_{2}$. For higher over-potential a second autocatalytic process occurs as proposed by Schmid [27-31]. This mechanism is based on the adsorption and reduction of $\mathrm{NO}^{+} / \mathrm{HNO}_{2}$ to form $\mathrm{NO}$ (valence II of nitrogen), which in turn reacts with $\mathrm{HNO}_{3}$ to form again $\mathrm{NO}^{+} / \mathrm{HNO}_{2}$. Both mechanisms correspond to an autocatalytic kinetics and it should be mentioned that the potential dependency of these 
processes was demonstrated by Razygraev [32, 33], who also showed that other mechanisms occur for larger cathodic over-potential. Moreover for both mechanisms, it is not $\mathrm{HNO}_{3}$ that directly exchanges the electrons with the steel, but a lower valence product $\left(\mathrm{NO}_{2}\right.$ or $\left.\mathrm{NO}^{+} / \mathrm{HNO}_{2}\right)$.

Despite these very complex processes, it is often considered that in first approximation, the reduction current is mainly due to the reduction of acid nitric into nitrous acid [15-19] according to:

$$
\mathrm{NO}_{3}^{-}+3 \mathrm{H}^{+}+2 e^{-} \rightleftharpoons \mathrm{HNO}_{2}+\mathrm{H}_{2} \mathrm{O}
$$

Conversely to the corrosion behavior of 304L SS in sulfuric acid solution which is well documented [34-49], the oxidation behavior of SS in hot and concentrated nitric acid has been poorly discussed in the literature [5, 6, 50-55], and it has mostly been studied through electrochemical methods only $[5,6,51-55]$. In this case, the use of usual electrochemical techniques may not be sufficient since only a global current is measured, which results from the addition of both anodic (oxidation of the SS) and cathodic (reduction of nitric acid) currents. It is thus intricate to separate these two contributions especially in the cathodic domain for which the anodic contribution is masked by a large cathodic current. It should be mentioned that such a behavior has already been shown for other materials, e.g. by Haupt and Strehblow for the corrosion of chromium in diluted sulfuric acid [56]. In this case, they were able to separate the anodic and cathodic contributions by measuring both the global current and the chromium release in solution with a rotating-ring disk electrode (RRDE) technique.

Even though electrochemical techniques are techniques of choice for the investigation of corrosion kinetics, a crude limitation is that only redox phenomena can be detected. For 
instance, in the case for SS in nitric acid in the transpassive domain, the corrosion process involves metal dissolution (detectable by electrochemistry) but also grain losses that cannot be detected by electrochemistry and which requires the concomitant use of other analysis techniques. Moreover for most of the authors $[5,51-55]$ the oxidation behavior of SS in such an aggressive solution was studied with dynamic electrochemical methods (cyclic voltammetry) $[5,51-55]$ and the stabilization time before measurement (when it is mentioned) was restricted to the range 10 minutes to 5 hours $[5,50,52-55]$. For these experiments, the extrapolation of the results to longer time is questionable, as it will be shown in the following.

Therefore, this work aims at studying the oxidation behavior of a 304L SS in nitric acid $4 \mathrm{~mol} / \mathrm{L}$ and at $100^{\circ} \mathrm{C}$. These conditions were chosen in order to be representative of the operation of some devices in a reprocessing plant for spent nuclear fuel. The variation of the corrosion kinetics of 304L SS and its surface properties (aspect, composition, thickness of passive film...) were studied as a function of the potential from the passive to the transpassive domain. A particular attention has been paid to characterize the steady-state of the system. For that purpose, chronoamperometry experiments were carried out at different potentials and for durations as long as 150 hours and different surface analysis techniques were used.

\section{Experimental}

\subsection{Materials}

The samples were obtained from a solution-annealed and quenched 304L stainless steel, in the form of a hot-rolled sheet provided by Tonnetot ( $65 \%$ deformation ratio). This SS is an austenitic steel with a low ferrite content (the ferrite to austenite ratio is $1.8 \%$ ), and, 
from SEM image analysis as shown in Figure 1, its average grain size is of about $45 \mu \mathrm{m}$ was obtained. Its nominal composition is given in Table 1 .

Table 1 - 304L stainless steel composition (in weight \%)

\begin{tabular}{|ccccccccc|}
\hline $\mathrm{Cr}$ & $\mathrm{Ni}$ & $\mathrm{Fe}$ & $\mathrm{Mn}$ & $\mathrm{Si}$ & $\mathrm{Al}$ & $\mathrm{P}$ & $\mathrm{C}$ & $\mathrm{S}$ \\
\hline 17.95 & 8.45 & Bal. & 1.45 & 0.61 & 0.005 & 0.036 & 0.015 & 0.025 \\
\hline
\end{tabular}

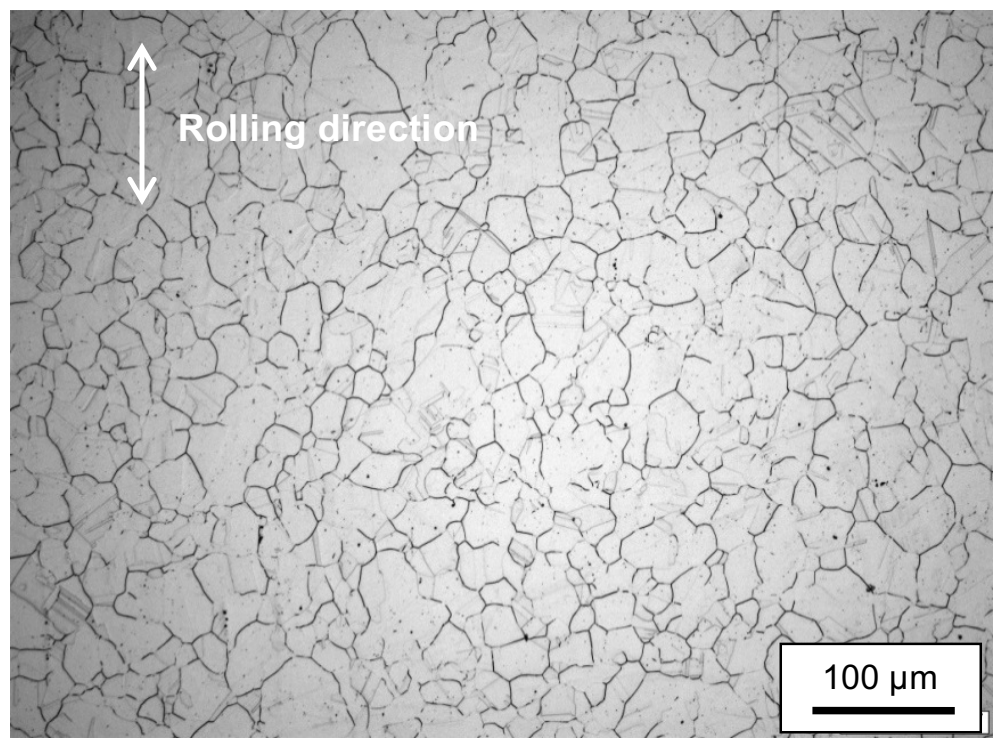

Figure 1 - 304L SS surface after a $5 \mathrm{~s}$ immersion in a solution composed of $1 / 3 \mathrm{H}_{2} \mathrm{O}-1 / 3 \mathrm{H}_{2} \mathrm{O}_{2}-1 / 3 \mathrm{HCl}$

A cuboid sample $\left(6 \times 20 \times 30 \mathrm{~mm}^{3}\right)$ was used for weight loss measurements. It was cut from the steel sheet by spark machining and machined to be mounted on a steel axis that was connected to the electrochemical workstation.

Before any experiment, the surface of the sample was prepared with an automated polisher (Struers Abramin), using silicon carbide papers with successive grades from 800 to 4000 for 2 minutes and then with a 3-micron diamond paste for 1 minute. The sample was rinsed with demineralized water and ethanol and dry with compressed air. As expected, complementary surface chemical analysis (X-Ray Photoelectron (XPS) analysis - see below for a description of the technique) showed that the steel surface is partially 
oxidized during the surface preparation process, resulting from polishing, rinsing and/or contact with ambient air. This initial oxide film is some nanometers thick and it is composed of $\mathrm{Fe}$ (in majority) and $\mathrm{Cr}$.

\subsection{Methods}

All experiments were performed in a $250 \mathrm{~mL}$ cell in a 3-electrode configuration. The working and the counter electrodes were the SS sample and a platinum basket, respectively. The reference electrode was a mercury sulfate electrode $\left(\mathrm{Hg}-\mathrm{Hg}_{2} \mathrm{SO}_{4}-\right.$ MSE, $E=0.658 \mathrm{~V}(\mathrm{SHE})$ protected from the electrolyte by a salt bridge. All the potentials in the paper are given $v s$. the Standard Hydrogen Electrode (SHE). The potentiostat used for all the experiments was a Biologic VMP. The electrolytic solution was a $4 \mathrm{~mol} / \mathrm{L}$ $\mathrm{HNO}_{3}$ solution prepared by diluting R.P. NORMAPUR PROLABO 52.5\% solutions with demineralized water.

\section{a. Pseudo steady-state anodic measurements}

After 65-hour immersion at the corrosion potential, both anodic and cathodic dynamic polarization curves were recorded independently at $1 \mathrm{mV} / \mathrm{min}$; first from the corrosion potential $(0.85 \pm 0.05 \mathrm{~V}(\mathrm{SHE}))$ towards lower higher potentials, and then (with another sample) from the corrosion potential towards higher potentials. By polarizing from the corrosion potential to cathodic or anodic over-potential, it was expected that the curves obtained are little influenced by the history of the polarization since it has already been shown that the aspect of the polarization curves in nitric acid solution was potential dependent [17]. This is mainly due to the autocatalytic reduction processes as discussed in the introduction section. 


\section{b. Steady-state anodic measurements}

The steady-state anodic behavior was studied with chronoamperometry experiments. The sample was firstly immersed at the open potential in solution for one hour prior to polarization. Then it was polarized at different potentials (from 0.3 to $1.3 \mathrm{~V}(\mathrm{SHE})$ ) on the passive and the transpassive domain (a different sample was used at each potential measurement). During all the experiments, the total current was measured in the cell as a function of time, and it corresponds to the sum of the cathodic and anodic currents. Thus, by the electrochemical measurement alone, it is not possible to measure independently both cathodic and anodic currents (especially near the corrosion potential, where both cathodic and anodic currents are in the same order of magnitude).

This is the reason why we measured mass loss (by weighting) simultaneously with total current. We assumed that the mass loss corresponds to steel oxidation/dissolution (this assumption will be discussed in details further in the paper). Using Faraday's law, the anodic current can be estimated from mass loss rate. Then by coupling current and mass loss measurements, we obtained both the cathodic and the anodic kinetics. To estimate the mass loss kinetics for each potential, the sample was periodically removed from the electrolyte to be weighted. Firstly, it was rinsed for $30 \mathrm{~min}$ with demineralized water and dried compressed air. Then it was stored in a desiccator at $22 \pm 1.5^{\circ} \mathrm{C}$ for at least $45 \mathrm{~min}$. Finally it was weighted with a balance XP205 from Mettler Toledo. The corrosion rate was estimated from the slope of mass loss as a function of time.

After weighting and before reintroducing the sample in the electrolyte, the corrosion morphology was observed with an inversed optical microscope (Olympus GX51) or a scanning electron microscope SEM (Leo 1450 VP Zeiss or Ultra 55 Zeiss).

For six potentials $(0.55-0.8-0.9-1.05-1.15-1.25 \mathrm{~V}(\mathrm{SHE}))$ on the passive and the transpassive domains, the chemical composition of the surface was also analyzed using 
X-Ray Photoelectron Spectroscopy (XPS). XPS analyses were carried out with a Thermofisher Escalab 250 XI spectrometer using a monochromatic X-ray Al $\mathrm{K}_{\alpha}$ source. The instrument was calibrated in energy with the silver Fermi-level $(0 \mathrm{eV})$ and the $3 \mathrm{~d} 5 / 2$ core level of metallic silver $(368.3 \mathrm{eV})$. The $\mathrm{C}-1 \mathrm{~s}$ signal was used to correct a possible charge effect: the $\mathrm{C}-\mathrm{C} / \mathrm{C}-\mathrm{H}$ contribution of $\mathrm{C}-1 \mathrm{~s}$ spectra was fixed at $285.0 \mathrm{eV}$. The analysis zone consisted in a $900 \mu \mathrm{m}$ in diameter spot. Data processing was performed using the commercially available Avantage software. The surface pollution of the samples was found to be sufficiently low that no etching was necessary to remove the pollution of the surface before the XPS analysis.

In the same time, for three potentials $(0.90,1.15$ and $1.25 \mathrm{~V}(\mathrm{SHE}))$, the concentration of $\mathrm{Fe}, \mathrm{Cr}$ and $\mathrm{Ni}$ in the solution was determined using Inductively Coupled Plasma Atomic Emission Spectroscopy (ICP-AES - Optima 2000 model from Perkin-Elmer).

Finally we estimated the oxide film thickness thanks to potentiostatic electrochemical impedance spectroscopy (EIS). The applied potential amplitude was chosen sufficiently small $(10 \mathrm{mV})$ to assure that the $J$ vs. $E$ response was linear in this domain (this was checked by performing EIS experiments with different potential amplitudes).

\section{Results and discussion}

\subsection{Pseudo-steady state anodic curve}

Linear sweep voltammetry was performed as a reference experiment for comparison with literature data $[5,51-55]$ and to discuss the interest to perform steady-state experiments. The total current density, $J_{\text {tot }}$, measured in the cell during dynamic polarization is shown in Figure 2. In this example, the corrosion potential $\left(E_{\text {corr }}\right)$ is at $0.82 \mathrm{~V}(\mathrm{SHE})$. For lower potential values than $E_{\text {corr }}, J_{\text {tot }}$ is negative indicating that the contribution of the reduction current is larger than the oxidation one. As a consequence, the total current measurement 
gives no information in this domain of potential on the presence of a possible anodic contribution, as further discussed in the paper.

At corrosion potential, an exchange current density of about $1 \mu \mathrm{A} / \mathrm{cm}^{2}$ was extrapolated from Tafel plot. This corresponds to a corrosion rate of about $10 \mu \mathrm{m} / \mathrm{y}$ (calculated from Faraday's law). The latter value is in good agreement with those estimated from mass loss measurements in the passive domain in Figure 4 (vide infra).

Above the corrosion potential, $J_{\text {tot }}$ is positive and therefore the anodic domain is obtained. From $E_{\text {corr }}$ to about $1.10 \mathrm{~V}(\mathrm{SHE}), J_{\text {tot }}$ is about few $\mu \mathrm{A} / \mathrm{cm}^{2}$, and corresponds to the passive behavior of the SS. In this domain, the current increases slowly with the potential, as previously shown $[5,53,55]$. However, in the passive domain, one can expect that $J_{\text {tot }}$ shows a constant value as a function of the potential. A possible explanation can be a non-negligible cathodic contribution to the current in the anodic domain. This cathodic contribution was obtained by extrapolating the cathodic current to higher potentials than the corrosion potential (Tafel's equation) (Figure 2). It was then subtracted to the total current $J_{\text {tot }}$ to estimate the anodic current (Figure 2). Despite this correction, it appears that the anodic current is not constant as a function of the potential, which should result from the dynamic character of the linear sweep voltammetry.

Above $1.10 \mathrm{~V}(\mathrm{SHE})$, the curve shows the transpassive behavior of the SS. The current was characterized by a drastic increase and intergranular corrosion was observed at the sample surface as well as grains at the bottom of the electrochemical cell. As electrochemical measurement is only sensitive to redox processes, grain dropping is not measured by linear sweep voltammetry and thus the real degradation in transpassive domain is probably underestimated. 


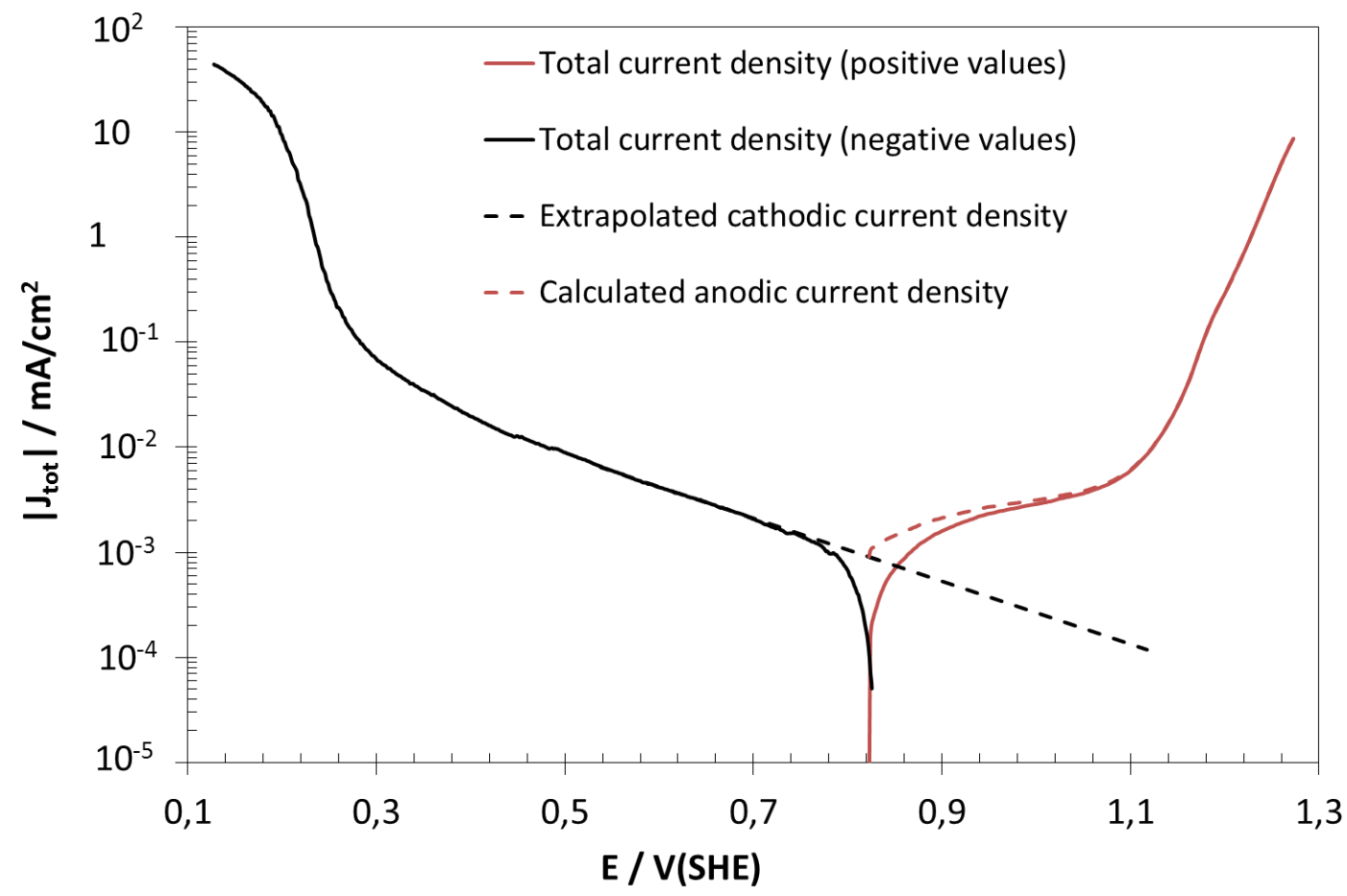

Figure 2 - Dynamic polarization curve obtained with $304 \mathrm{~L} \mathrm{SS}$ in $\mathrm{HNO}_{3} 4 \mathrm{~mol} / \mathrm{L}$ at $100^{\circ} \mathrm{C}-\mathrm{d} E / \mathrm{d} t=1 \mathrm{mV} / \mathrm{min}$, stabilization time before polarization: $65 \mathrm{~h}$. The extrapolated cathodic current density and the calculated anodic current density are also shown on the graph.

\subsection{Steady state anodic behavior}

In order to determine the experimental conditions required for reaching the steady-state behavior of the corroding system, chronoamperometry experiments were carried out at different potentials between 0.30 and $1.30 \mathrm{~V}(\mathrm{SHE})$. After a period of $\Delta t$ hours of polarization, the mass loss, $\Delta m$, was used to define an equivalent thickness loss, $\Delta e_{\mathrm{m}}$, assuming a homogeneous dissolution of the material according to the following relationship:

$$
\Delta e_{\mathrm{m}}=\frac{\Delta m}{\rho_{\mathrm{SS}} \cdot S}
$$

where $S$ is the geometrical surface area of the sample, and $\rho_{\mathrm{ss}}$ is the density of the SS $\rho_{\mathrm{ss}}$ $=7.8 \mathrm{~kg} / \mathrm{dm}^{3}$.

Figure 3 illustrates the evolution of $\Delta e_{\mathrm{m}}$ as a function of time in the cases of four representative potentials $(0.90,1.05,1.15$, and $1.25 \mathrm{~V}(\mathrm{SHE}))$. 


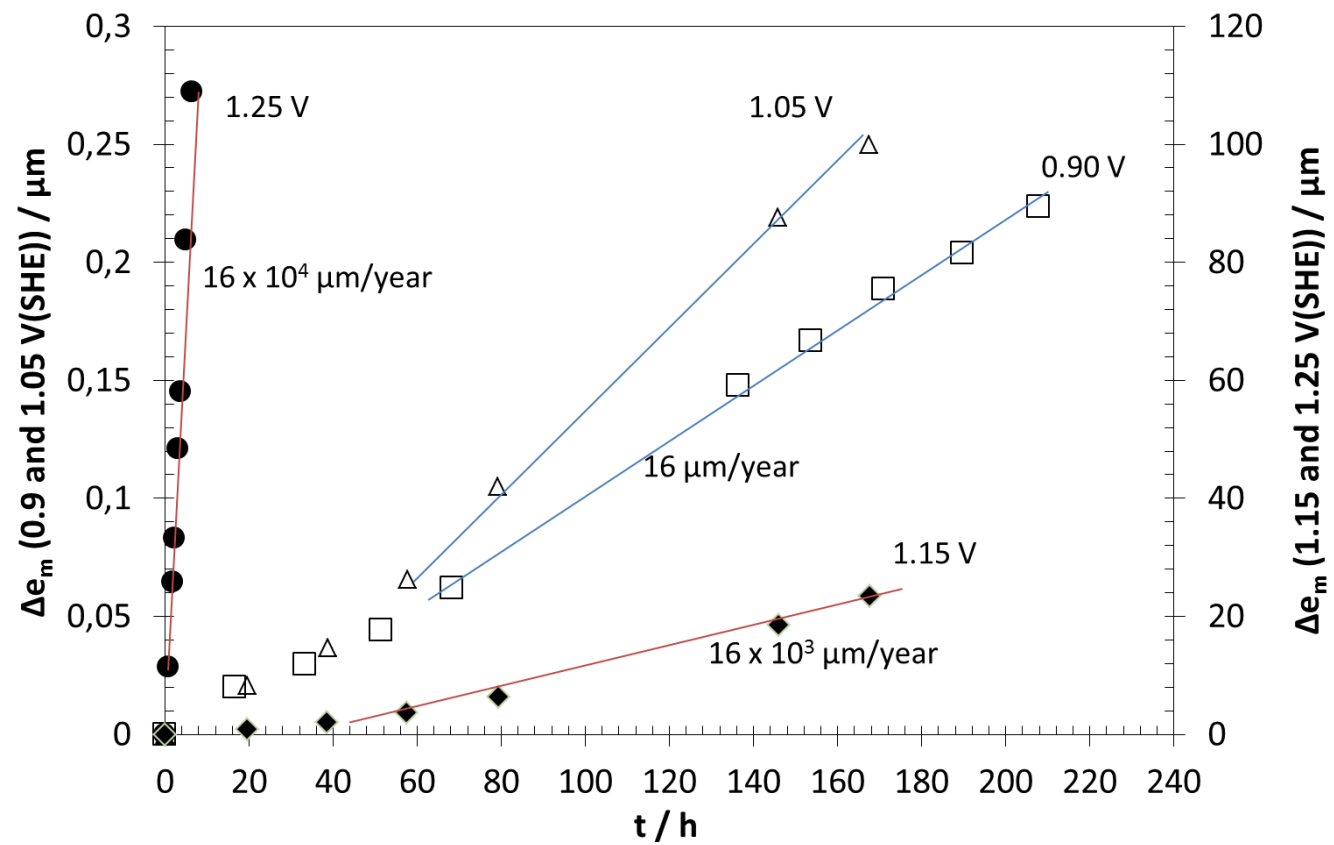

Figure 3 - Equivalent thickness loss as a function of time for 304L SS polarized at 0.90 and $1.05 \mathrm{~V}(\mathrm{SHE})$ (left axis), and at 1.15 and $1.25 \mathrm{~V}(\mathrm{SHE})$ (right axis) in $\mathrm{HNO}_{3} 4 \mathrm{~mol} / \mathrm{L}$ at $100{ }^{\circ} \mathrm{C}$. The lines correspond to the corrosion rate at steady-state.

The results obtained for potentials in the range $0.30-1.05 \mathrm{~V}(\mathrm{SHE})$ are similar to the example presented in Figure 3 at 0.90 and $1.05 \mathrm{~V}(\mathrm{SHE})$. The evolution of $\Delta e_{\mathrm{m}}$ as a function of time is linear only after an immersion of about $50 \mathrm{~h}$, indicating that several hours may not be sufficient to reach the steady-state behavior for this corroding system $[5,50,52-55]$. After $50 \mathrm{~h}$, the slope of the line allows a corrosion rate of about $10 \mu \mathrm{m} /$ year to be determined. This value is almost independent of the potential in the range $0.30-1.05 \mathrm{~V}(\mathrm{SHE})$ (Figure 3).

For potential larger than $1.10 \mathrm{~V}(\mathrm{SHE})$ (see for examples the curves obtained at 1.15 and 1.25 V(SHE) in Figure 3), the behavior is rather different and depends on the potential: the corrosion rate strongly increases and the time required for reaching steady-state decreases notably when the potential increases.

\subsection{Steady state mass loss rate and surface aspect evolution as a function of the potential}


For each electrode potential, at steady state, the mass loss rate $V_{\mathrm{m}}$ was calculated from the equivalent thickness loss $\Delta e_{\mathrm{m}}$ after a duration $\Delta t$ according to the following relationship:

$$
V_{\mathrm{m}}=\frac{\Delta e_{\mathrm{m}}}{\Delta t}
$$

The evolution of $V_{\mathrm{m}}$ as a function of the potential is plotted in Figure 4. It shows an increase of the corrosion rate of about 3 orders of magnitude in the transpassive domain (i.e. in the potential range $1.1-1.3 \mathrm{~V}(\mathrm{SHE})$ ), whereas it is almost constant over the whole passive domain.

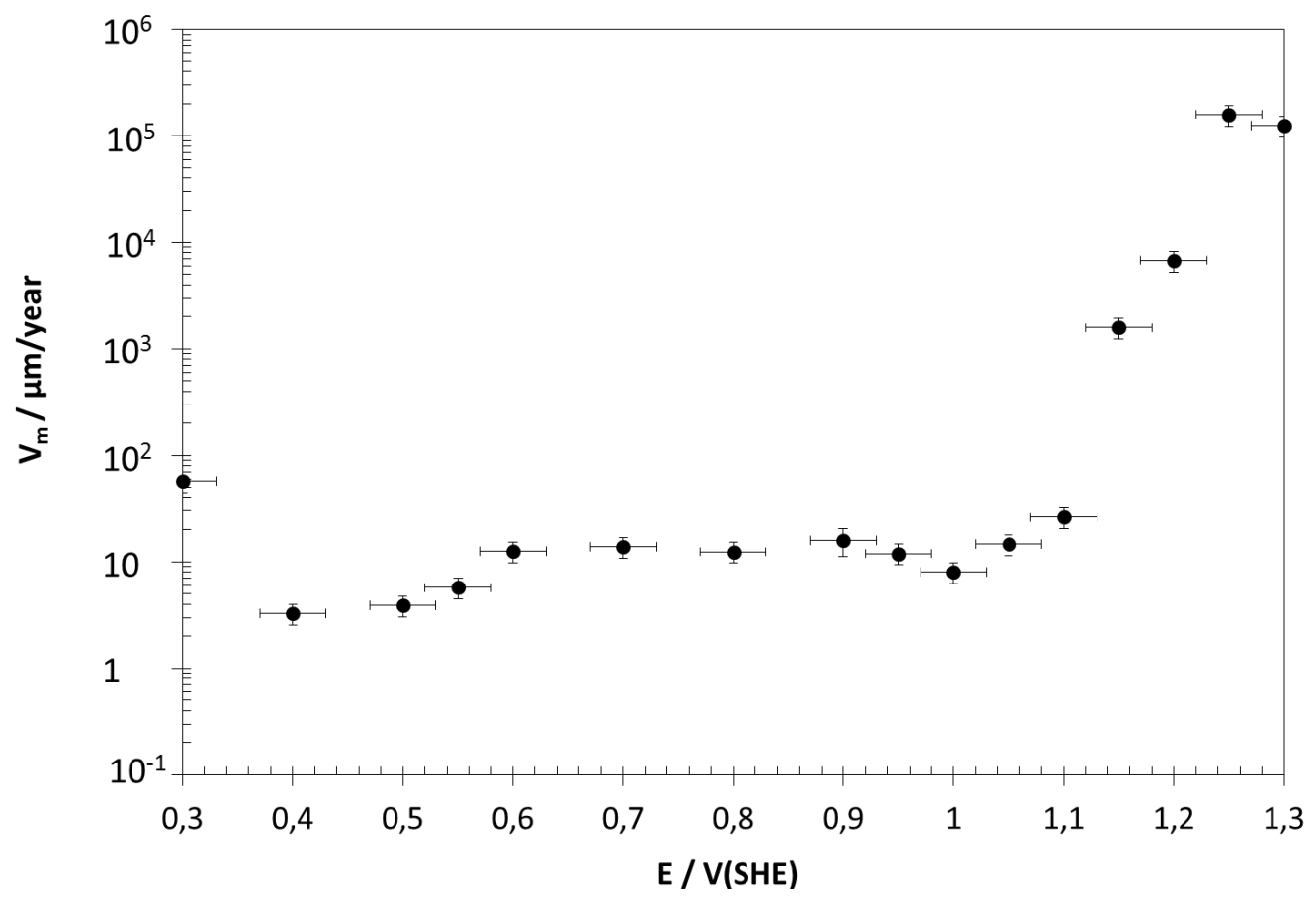

Figure 4 - Evolution of the corrosion rate $V_{\mathrm{m}}$ determined from mass loss measurements at steady-state as a function of the potential for an electrode of $304 \mathrm{~L} \mathrm{SS}$ in $\mathrm{HNO}_{3} 4 \mathrm{~mol} / \mathrm{L}$ at $100^{\circ} \mathrm{C}$.

Figure 5 shows the evolution of the surface aspect observed by optical microscopy as a function of potential at the end of the linear sweep voltammetry experiments. As previously discussed the aspect is characteristic of a steady-state evolution of the interface. Interestingly, the transition between the passive and the transpassive domain can be clearly seen with the apparition of intergranular corrosion for potential larger than 1.05 V(SHE). The corresponding cross sections are presented in Figure 6. 

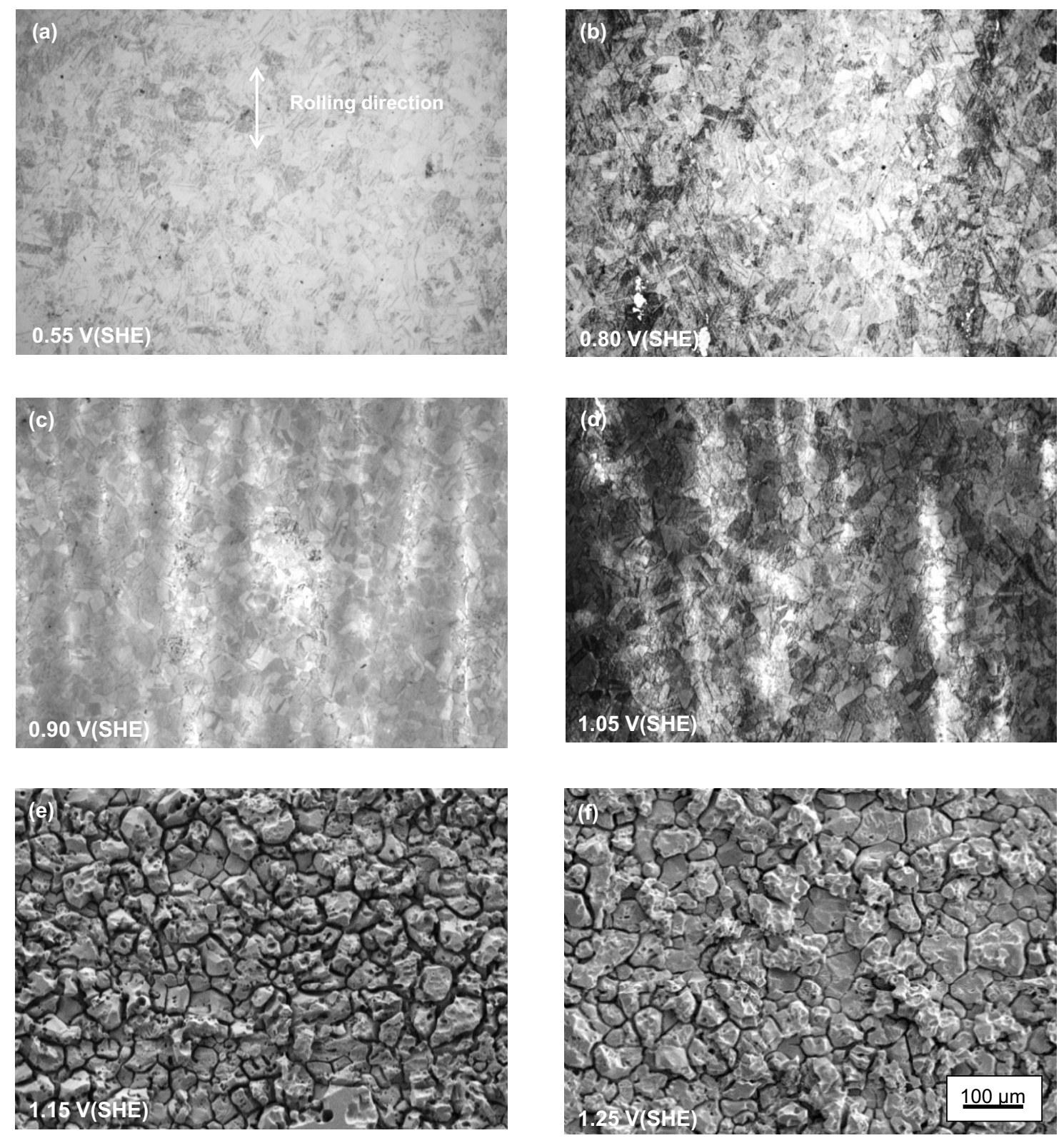

Figure 5 - Surface observations (with optical microscope (a) - (d); with scanning electron microscope (e) - (f)) of 304 L SS electrodes after polarization at different potentials in $\mathrm{HNO}_{3} 4 \mathrm{~mol} / \mathrm{L}$ at $100^{\circ} \mathrm{C}$. (a) $0.55 \mathrm{~V}$ (SHE), (b) 0.80 V(SHE), (c) $0.90 \mathrm{~V}$ (SHE), (d) 1.05 V(SHE), (e) $1.15 \mathrm{~V}$ (SHE), (f) $1.25 \mathrm{~V}$ (SHE) 

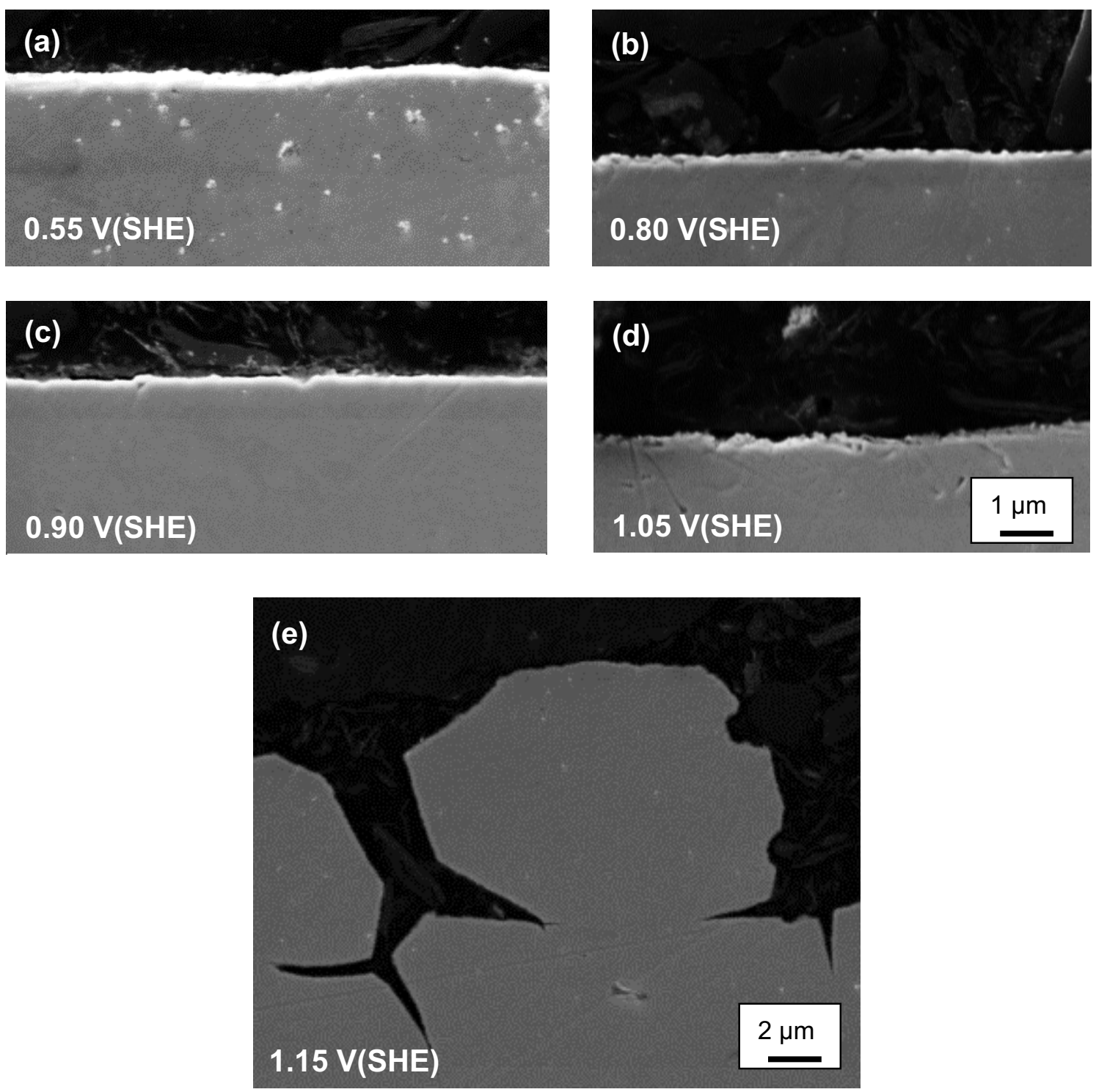

Figure 6 - Cross section observations with optical microscope of 304L SS electrodes after polarization at different potentials in $\mathrm{HNO}_{3} 4 \mathrm{~mol} / \mathrm{L}$ at $100^{\circ} \mathrm{C}$. (a) $0.55 \mathrm{~V}$ (SHE), (b) $0.80 \mathrm{~V}$ (SHE), (c) $0.90 \mathrm{~V}$ (SHE), (d) 1.05 $\mathrm{V}(\mathrm{SHE})$, (e) $1.15 \mathrm{~V}(\mathrm{SHE})$

These optical observations combined to corrosion rate measurements allowed three potential domains to be evidenced.

For an applied potential of $0.30 \mathrm{~V}(\mathrm{SHE})$, the mass loss rate is at about $60 \mu \mathrm{m} / \mathrm{year}$, which corresponds to a relatively high corrosion rate compared to the results obtained at higher potentials. This potential corresponds to the end of the active area and the beginning of the passive domain. In the active regime, it is known that the dissolution is important and uniform corrosion is often mentioned [37]. 
In the potential range from 0.40 to $1.05 \mathrm{~V}(\mathrm{SHE})$, the corrosion rate is almost constant and lower than $10 \mu \mathrm{m} /$ year, which corresponds to the passive domain of the $\mathrm{SS}$ in $\mathrm{HNO}_{3} 4$ $\mathrm{mol} / \mathrm{L}$ at $100^{\circ} \mathrm{C}$. This result has to be compared with dynamic polarization results for which an increasing oxidation current was recorded, which leads to an overestimation of the kinetics, and in turn to an overestimation of the corrosion rate. Interestingly, the surface appearance and morphology are also similar from one potential to another in this potential range. However, the surface defects and in particular the grain boundaries are preferential sites for dissolution as observed Padhy et al. [6]. Cross-sections of the surface samples after long-term polarization show a low surface roughness that does not vary significantly with the potential (Figure 6). A detailed analysis of the results obtained in the passive domain shows some variability for the corrosion rate as well as the surface that becomes darker as the potential increases. This evolving behavior in the passive domain was already observed for the corrosion of SS in sulfuric acid, which shows the presence of a minimum of the corrosion rate in the passive domain $[39,57,58]$.

Above $1.05 \mathrm{~V}(\mathrm{SHE})$, the corrosion rate increases sharply with the potential corresponding to the transpassive domain. This behavior is consistent with results observed for steels in different acidic solutions [57]. It is commonly accepted that this transpassive behavior results from the oxidation of chromium at valence VI, which is less protective than chromium III $\left(\mathrm{Cr}_{2} \mathrm{O}_{3}\right)$. Moreover, the particular morphology of intergranular corrosion (IGC) is observed. IGC results from the specific reactivity of grain boundary, comparing to reactivity of the grain itself. The grain boundary reactivity can be attributed to chemical reasons (associated with the presence of segregations at grain boundaries) [11, 59-61]. It is shown that both phosphorus [62-73] and silicon $[5,7,62,67-72,74-91]$ have an impact on the occurrence and kinetics of IGC. It can also be due to the specific reactivity of grain boundaries as proposed in $[11,60,62,74,92,93]$, in which the grain 
boundary structure, especially the relative misorientation of adjacent grains, impacts the kinetics of grain boundary attack. This leads to the formation of grooves at grain boundaries. The progression of these grooves inside the steel can induce grain dropping. Some authors proposed that this IGC morphology results from the existence of two different dissolution rates: a dissolution rate of grain surface and a dissolution rate of grain boundary. Based on this phenomenology, it was theoretically shown that the weight loss of the steel is ascribable to two contributions: steel oxidation / dissolution and grains dislodgment [13].

\subsection{Current densities in the steady state}

Figure 7 shows two different current density curves as a function of the applied potential corresponding to the steady state total current density $J_{\text {tot }}$ (obtained by measuring the current with the potentiostat) and the steady state current density calculated from the mass loss measurements, $J_{\mathrm{m}}$. It was estimated using the Faraday's law:

$$
J_{\mathrm{m}}=\frac{n \cdot F \cdot \Delta m}{S M \Delta t}
$$

where $F$ is the Faraday's constant, $M$ the molar mass of the SS, and $n$ the number of exchanged electrons. The latter depends on the SS potential and is calculated with thermodynamic data:

$$
n=\sum_{i=F e, C r, N i} x_{i} \alpha_{i}
$$

with $x_{i}$ the mole ratio of the specie $i(\mathrm{Fe}, \mathrm{Cr}$ or $\mathrm{Ni})$ and $\alpha_{i}$ the mean degree of oxidation of the redox couple estimated by its standard potential and the Nernst equation.

In the passive domain, $n$ was calculated considering oxidation of metallic species to $\mathrm{Ni}(\mathrm{II}), \mathrm{Fe}(\mathrm{III})$, and $\mathrm{Cr}(\mathrm{III})$. This two last species are the oxidation states of species that 
constitutes the oxide layer, which will be discussed further (vide infra). For potentials below $0.7 \mathrm{~V}(\mathrm{SHE})$ oxidation to Fe(II) was also introduced.

In the transpassive domain, thermodynamic data show the oxidation of $\mathrm{Fe}$ to $\mathrm{Fe}(\mathrm{III})$ and $\mathrm{Ni}$ to $\mathrm{Ni}(\mathrm{II})$. For the oxidation state of $\mathrm{Cr}$, an independent study of the material at 1.15 and 1.25 $\mathrm{V}(\mathrm{SHE})$ was performed (data not shown) involving mass loss, thickness loss due to grain dislodgment, thickness loss due to metal dissolution (by ICP-AES) and thickness loss due to electrochemical dissolution. It was shown that $\mathrm{Cr}$ was oxidized to $\mathrm{Cr}(\mathrm{VI})$ on this potential domain.

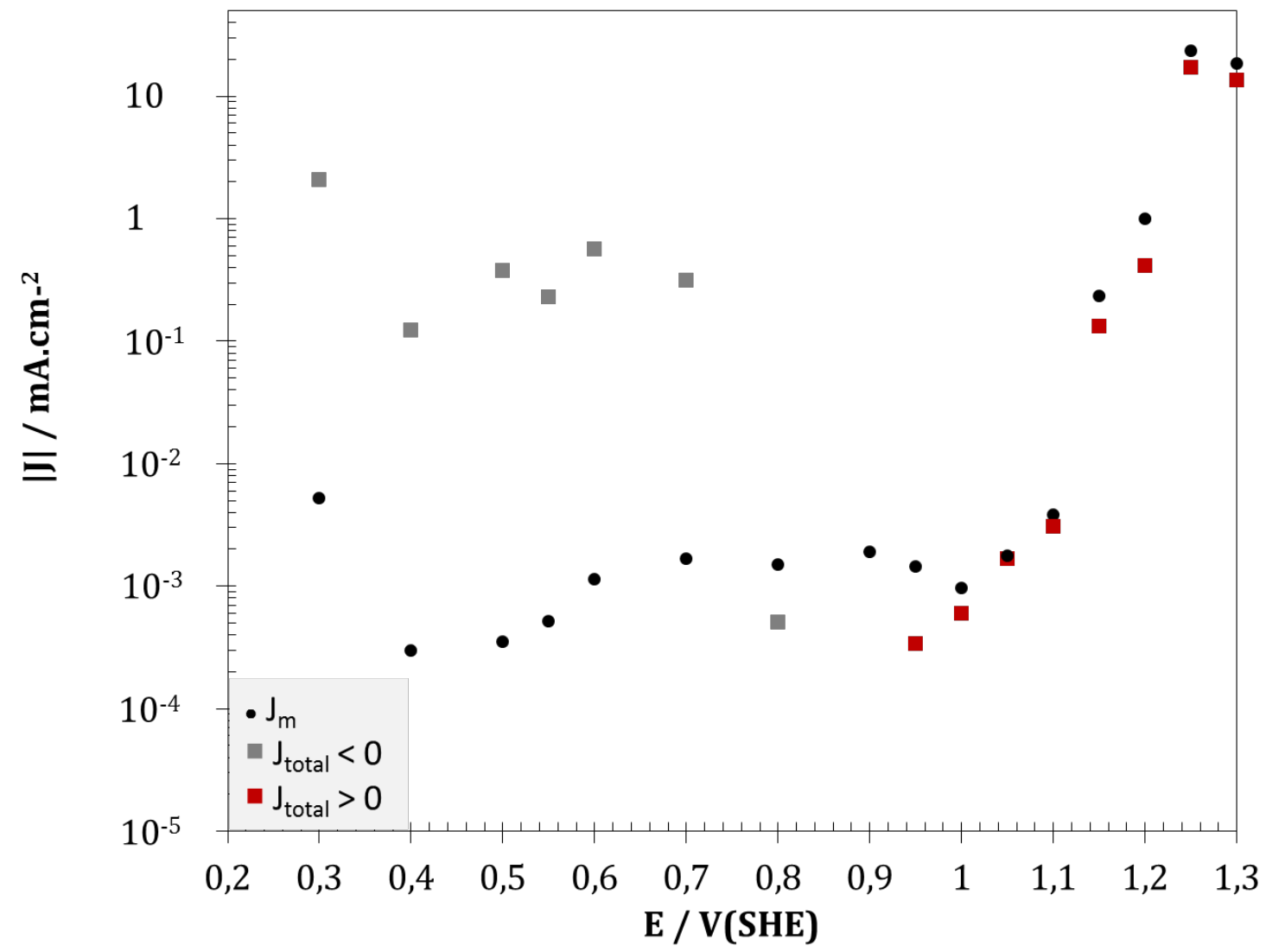

Figure 7 - Steady state total current density exchanged in the cell $J_{\text {total }}($ red and grey symbols), steady state weight loss current density $J_{m}$ (black dots) as a function of the potential for $304 \mathrm{~L} \mathrm{SS} \mathrm{in} \mathrm{HNO}_{3} 4 \mathrm{~mol} / \mathrm{L}$ at $100^{\circ} \mathrm{C}$

Below the corrosion potential (i.e. for potentials lower than $0.8 \mathrm{~V}(\mathrm{SHE})$ ) the total current density is ascribed to $\mathrm{HNO}_{3}$ reduction. The value of the steady state total current density $J_{\text {tot }}$ is larger than the value of the total current density measured with dynamic 
polarization (Figure 2). Such a behavior is to be ascribed to the autocatalytic mechanism that takes place for concentrated nitric acid reduction [16-19].

In addition, the comparison of the mass loss current density $J_{\mathrm{m}}$ with $J_{\text {tot }}$ shows that both oxidation and reduction occurs simultaneously, even in the range of the reduction of nitric acid. However, for potentials below $0.80 \mathrm{~V}(\mathrm{SHE}), J_{\mathrm{m}}$ is about three orders of magnitude lower than $J_{\text {tot }}$ and slightly depends on the potential.

Above the corrosion potential, $J_{\text {tot }}$ is always smaller than $J_{\mathrm{m}}$ in the passive domain, whereas no grain dislodgment was observed. This result indicates that reduction of $\mathrm{HNO}_{3}$ cannot be neglected in this potential domain. Conversely, in the transpassive domain, $J_{\mathrm{m}}$ is also larger than $J_{\text {total, }}$ but this difference can be, at least partially, attributed to grain loss.

\subsection{XPS analysis as a function of the electrode potential}

For different polarization potentials reported in Figure 7, an XPS survey spectrum was recorded. It was shown that the major components present at the surface of the SS were iron, chromium, nickel, and oxygen, whereas some other elements were also detected (e.g. $\mathrm{C}, \mathrm{Ca}$ ) corresponding to pollution of the sample surface during its preparation and/or storage. In the following, these elements were not considered in the quantification procedure.

A typical Ni-2p spectrum presented in Figure 8(a) shows one peak at $852.8 \pm 0.3 \mathrm{eV}$ (and the presence of a lower intensity peak at a higher energy at $860 \mathrm{eV}$ ) associated to metallic nickel [14]. The Fe-2p spectrum shows Figure 8 (b) is composed of an asymmetrical peak $(707.1 \pm 0.3 \mathrm{eV})$ and a symmetrical peak $(710.1 \pm 0.3 \mathrm{eV})$ respectively associated to metallic iron $\mathrm{Fe}(0)$ and oxidized iron Fe(III) [94]. Based on Marchetti et al. [95] and Gupta et al. [96, 97], we decomposed the $\mathrm{Cr}$ spectrum shows in Figure 8 (c) into 4 
different contributions. The peak at $574.0 \pm 0.3 \mathrm{eV}$ is ascribed to metallic $\mathrm{Cr}$, whereas the three other peaks at 575.7, 576.9, and $578.3 \pm 0.3 \mathrm{eV}$ are associated to $\mathrm{Cr}(\mathrm{III})$. Note that for at $1.15 \mathrm{~V}$ (SHE) (not shown), an additional peak is observed, which is due to the presence of $\mathrm{Cr}(\mathrm{VI})$ simultaneously with $\mathrm{Cr}(\mathrm{III})$ [98]. The presence of $\mathrm{Cr}(\mathrm{VI})$ in the oxide corroborates its role in the transpassive behavior of the steel. Interestingly, $\mathrm{Cr}(\mathrm{VI})$ is no longer detected at $1.25 \mathrm{~V}(\mathrm{SHE})$. 

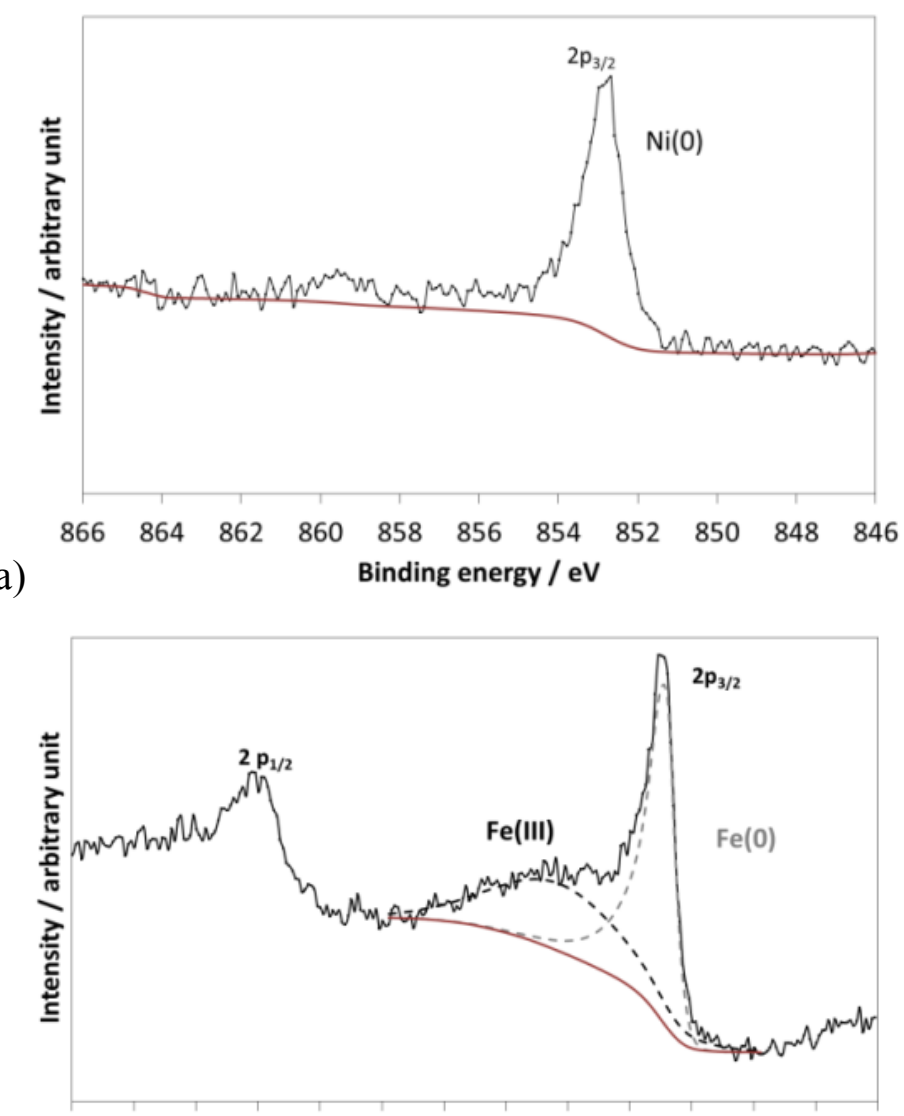
(b)

$\begin{array}{llllllllllllll}726 & 724 & 722 & 720 & 718 & 716 & 714 & 712 & 710 & 708 & 706 & 704 & 702 & 700\end{array}$

Binding energy / eV

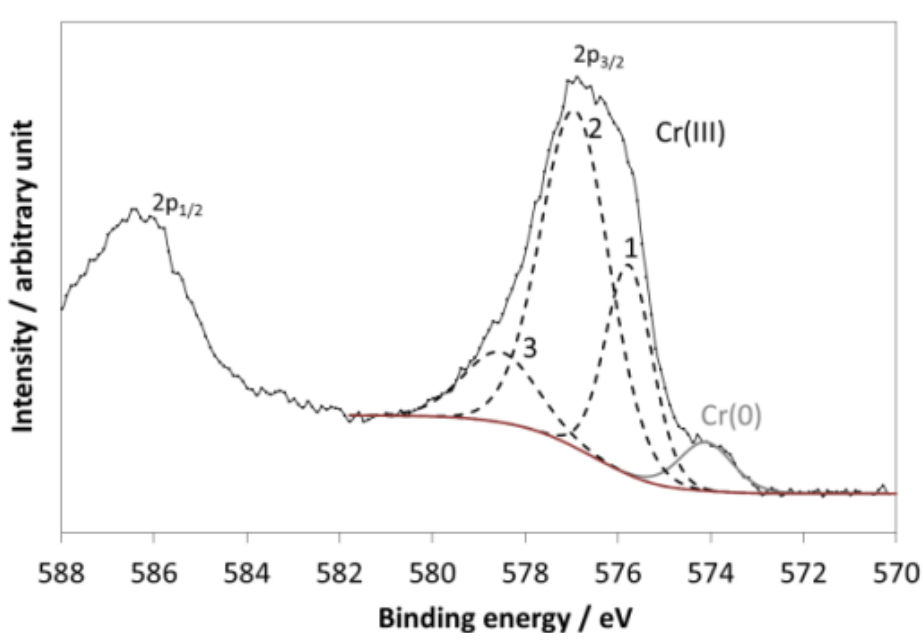

Figure 8 - (a) Ni-2 $\mathrm{p}_{3 / 2}$, (b) Fe-2p, (c) Cr--XPS spectra obtained on a 304L SS at $E_{\text {corr }}$ in $\mathrm{HNO}_{3} 4 \mathrm{~mol} / \mathrm{L}$ at $100{ }^{\circ} \mathrm{C}$ 


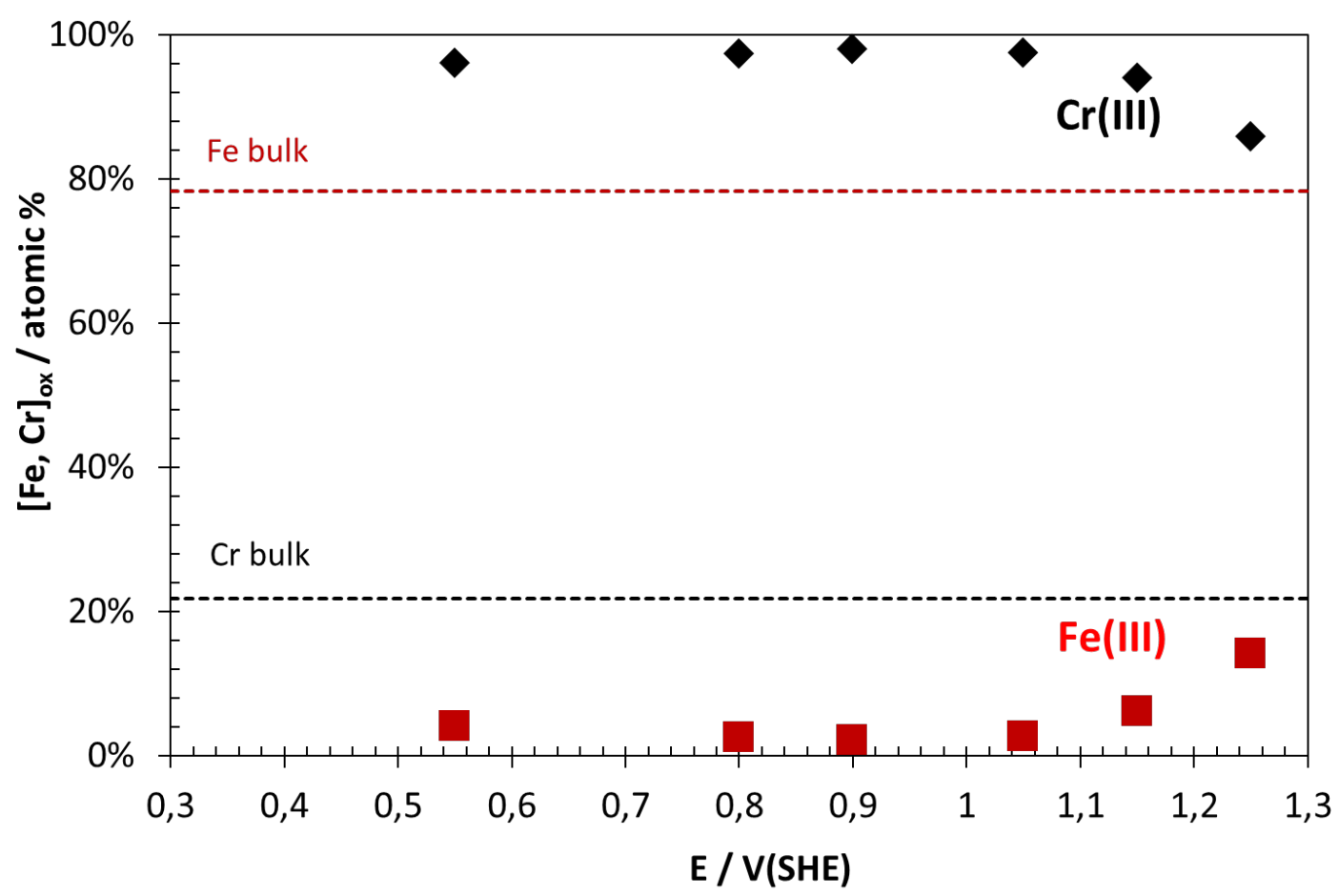

Figure 9 - Chemical composition of the oxide film as a function of the potential (XPS analysis) - 304L SS - $\mathrm{HNO}_{3}$ $4 \mathrm{~mol} / \mathrm{L}-100^{\circ} \mathrm{C}$. Each point corresponds to a mean value corresponding to at least $4 \mathrm{XPS}$ analyses on the surface

The relative composition of elements was estimated from the area under the peaks assuming that oxidized elements are part of the top oxide layer whereas the detected metallic elements are located under the oxide layer. $\mathrm{Fe}, \mathrm{Ni}$ and $\mathrm{Cr}$ are all observed under their oxidized form. Nevertheless the contribution of oxidized nickel to the total oxides is negligible. Therefore, the oxide layer is mainly composed of Fe and Cr. The evolution of the oxide layer composition as a function of the potential is shown in Figure 9. The relative concentrations of $\mathrm{Fe}$ and $\mathrm{Cr}$ in the oxide layer were calculated from:

$$
[M]_{\mathrm{ox}}=\frac{M_{\mathrm{ox}}}{C r_{\mathrm{ox}}+F e_{\mathrm{ox}}}
$$

where $[M]_{\text {ox }}$ corresponds to the relative concentration (in atomic \%) of the element $M$ (Fe or $\mathrm{Cr}$ ) in the oxide and $M_{\mathrm{ox}}$ corresponds to the concentration (in atomic \%) of the element with respect to all elements considered in the quantification. Concerning the metallic elements, $\mathrm{Fe}, \mathrm{Ni}$, and $\mathrm{Cr}$ are all observed under their metallic form. Nevertheless 
the contribution of metallic chromium to total chromium is very low and cannot be precisely quantified. Only the metallic contribution of iron and nickel could have been precisely quantified.

On the whole potential domain spreading up to $1.05 \mathrm{~V}(\mathrm{SHE})$, an enriched chromium oxide layer is present on the top surface with a relative ratio of $90 \% \mathrm{Cr}$ to $10 \% \mathrm{Fe}$. Such high chromium content makes the thin layer resistive against corrosion and it is noteworthy to note that its composition is constant throughout the potential range. These observations allow explaining that the oxidation current measured in the passive range is low and independent of the potential. This high chromium enrichment is in agreement with the work of Robin et al. who observed such a passive oxide formed on a 304L SS surface in nitric acid [5]. It results probably from the selective dissolution of iron against chromium during the oxide layer formation, as shown in sulfuric acid [99].

On the other hand, the $\mathrm{Ni} / \mathrm{Fe}$ ratio of metallic contributions is equal to about 0.9 , independently of the potential up to $1.05 \mathrm{~V}(\mathrm{SHE})$. This ratio is largely higher than in the steel (around 0.1), which shows a relative enrichment of nickel found in the underlying metallic layer. To the best of our knowledge, this nickel enrichment in the underlying metallic layer was reported once in dilute sulfuric acid [34]. The enrichment in nickel at the metal/oxide interface remains unclear on the corrosion processes of stainless steels in nitric acid.

Above $1.15 \mathrm{~V}(\mathrm{SHE})$, the oxide layer remains relatively enriched in chromium compared to iron, but the relative chromium enrichment decreases as the potential increases. This has to be correlated with the sharp increase of the oxidation current observed in the transpassive domain (Figure 7). Interestingly, the presence of an underlying metallic layer enriched in nickel is also observed at $1.25 \mathrm{~V}(\mathrm{SHE})$ but with a lower $\mathrm{Ni} / \mathrm{Fe}$ ratio (0.7).

\subsection{Electrochemical impedance spectroscopy characterization of the passive layer}


Figure 10 shows an example of EIS spectrum performed after 50 hours polarization at $0.90 \mathrm{~V}(\mathrm{SHE})$. The analysis of EIS spectrum reveals two time constants on the frequency domain investigated (Figure 11). In the case of Martensitic SS in neutral chloride solution [100], the high frequency (HF) response of the spectrum has been attributed to the oxidation processes. In this study, the HF response was also assumed to correspond to the anodic behavior of the sample while the low-frequency time constant has been ascribed to the reduction of nitric acid. Thus, HF response was used to analyze the oxide layer properties. In this frequency domain, the shape of the spectrum is characterized by a nonideal behavior and a constant phase element (CPE) was then introduced to account for the capacitive behavior of the oxide film [47]:

$$
Z_{\mathrm{CPE}}=\frac{1}{Q(\mathrm{j} \omega)^{\alpha}}
$$

where $\alpha$ and $Q$ are the CPE parameters, and were determined graphically $(0.85<\alpha<0.9$ and $\left.Q \approx 4 \times 10^{-5} \mathrm{~F}_{\mathrm{cm}}{ }^{2} \cdot \mathrm{s}^{\alpha-1}\right)$ (Figure 10).

This CPE behavior was associated to a normal distribution of time constants in the film corresponding to a distribution of resistivity according to the power law model [47]. Using the power law distribution of resistivity at the metal/oxide/electrolyte interface, the passive layer thickness, $d$, was estimated with the following relationship:

$$
d=\frac{\left(\varepsilon \varepsilon_{0}\right)^{\alpha}}{Q g \rho_{\delta}^{(1-\alpha)}}
$$

where $\varepsilon=12$ is the mean dielectric constant of $\mathrm{Cr}_{2} \mathrm{O}_{3}$ and $\mathrm{Fe}_{2} \mathrm{O}_{3}$ [101] and $\varepsilon_{0}$ is the permittivity of the vacuum. For the determination of $d$, the value of the resistivity at the metal/oxide interface, $\rho_{\delta}$ was assumed to be $450 \Omega . c m$ [47] and $g$ was numerically evaluated and is a function of $\alpha$. The interface effective capacitance was calculated, $a$ posteriori, with a formula that is defined with the power law model [47]: 


$$
C_{\text {eff }}=g Q\left(\rho_{\delta} \varepsilon \varepsilon_{0}\right)^{(1-\alpha)}
$$

For the impedance diagram presented in Figure 10, a $3 \mathrm{~nm}$ thick oxide layer was found. This value corresponds to a capacitance of about $4 \mu \mathrm{F} / \mathrm{cm}^{2}$, in agreement with usual value encountered for an oxide layer capacitance and lower than a double layer capacitance in a concentrated electrolytic solution [102]. 
(a)

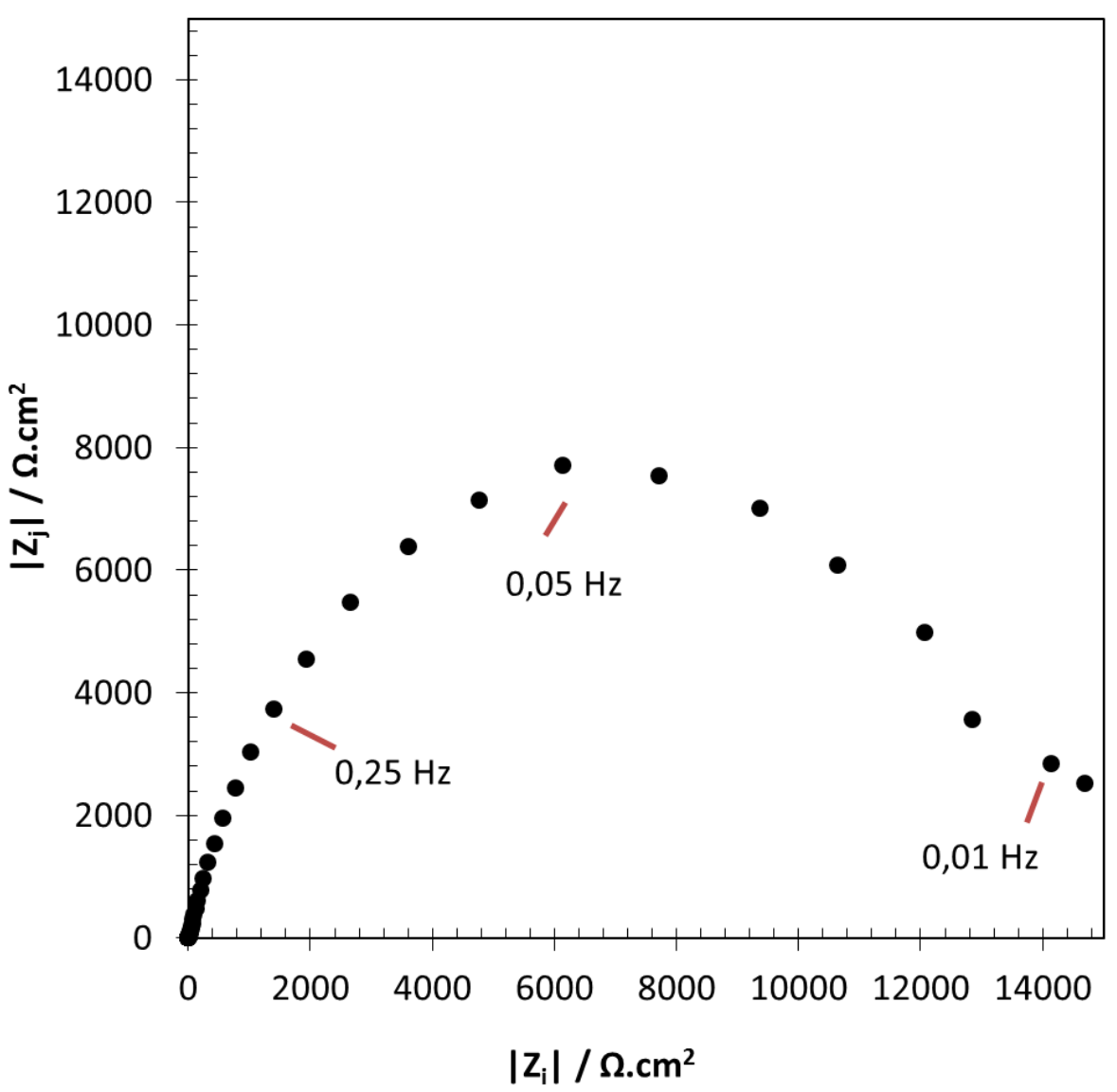

(b)

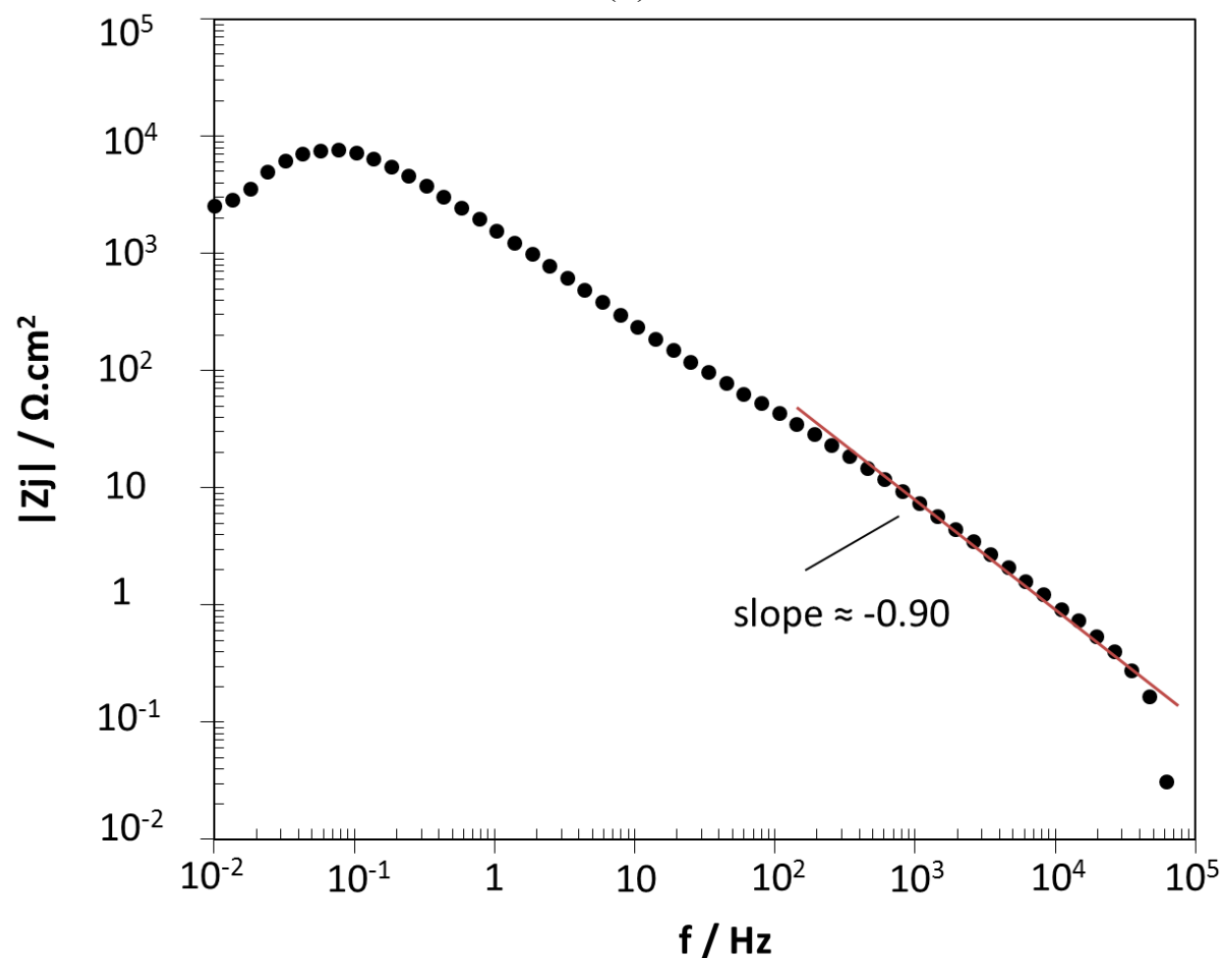

Figure 10 - Experimental impedance data obtained after 50 hours of polarization at $0.90 \mathrm{~V}(\mathrm{SHE})$ of 304L SS electrode in $\mathrm{HNO}_{3} 4 \mathrm{~mol} / \mathrm{L}$ at $100^{\circ} \mathrm{C}$ (a) Nyquist plot; and (b) imaginary part of the impedance as a function of frequency (the slope of the HF range corresponds to $\alpha$ ) 


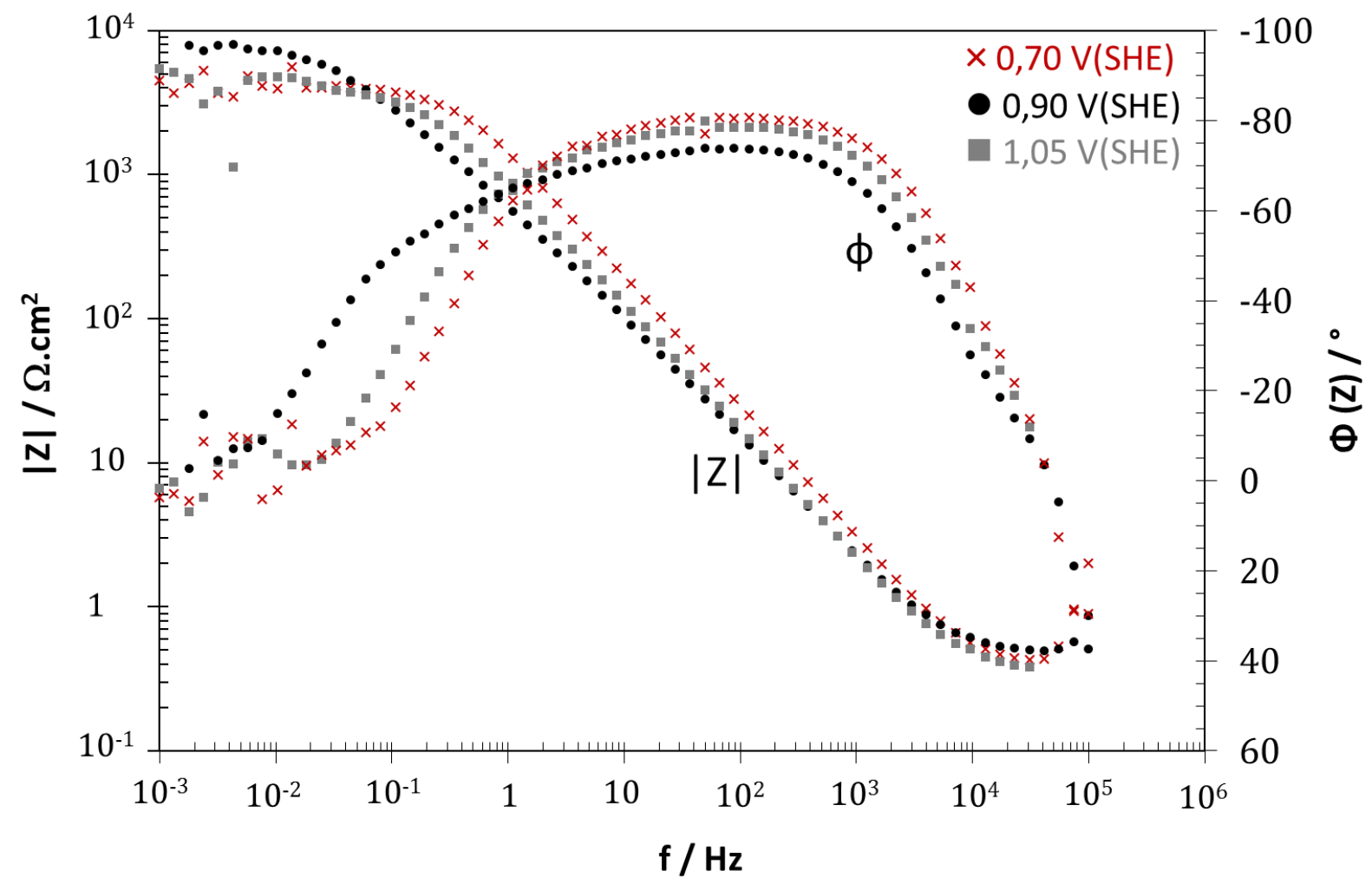

Figure 11 - Impedance modulus and phase as a function of the frequency (log-log scale) of 304L SS electrodes polarized at $0.70,0.90$ and $1.05 \mathrm{~V}(\mathrm{SHE})$ in $\mathrm{HNO}_{3} 4 \mathrm{~mol} / \mathrm{L}$ at $100^{\circ} \mathrm{C}$

From impedance data obtained at different potentials, the thickness evolution was determined for 4 different potentials in the passive domain. The evolution of $d$ is shown as a function of potential in Figure 12. The thickness of the oxide film $d$ is a few nanometers and increases with the potential. Similarly to the results obtained by Haupt [37] and Hara [38] in dilute sulfuric acid solution, the oxide layer growths as a function of the potential in the passive domain. This evolution has to be linked to the change in mass loss rate and the evolution of the surface aspect in the passive domain previously mentioned. These values are in agreement with the fact that XPS analyses showed that the thickness of the oxide layer is less than $10 \mathrm{~nm}$. Indeed a metallic contribution is always observed on XPS spectra, which means that the oxide layer is thinner than the XPS analysis depth (about $10 \mathrm{~nm}$ ). 


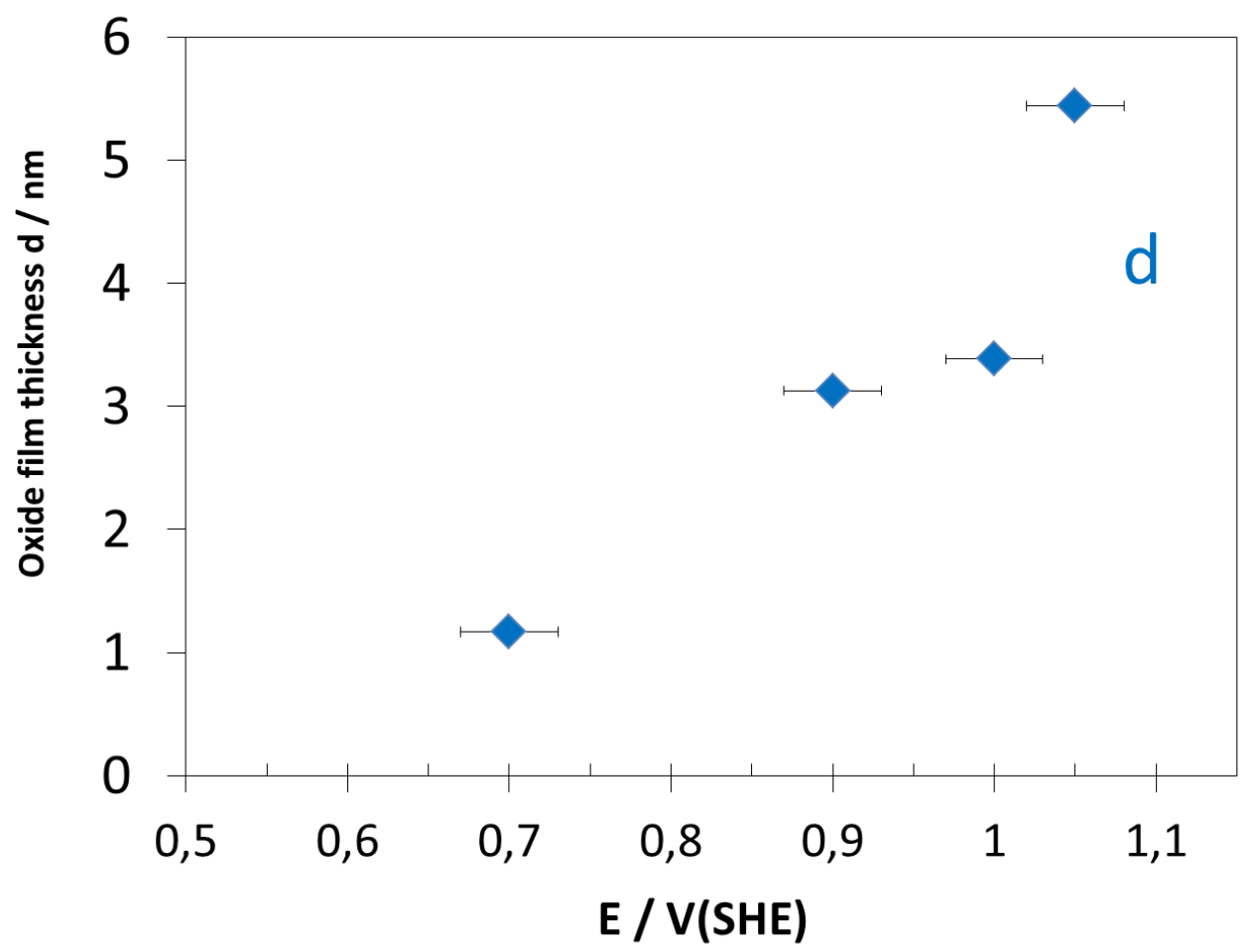

Figure 12 - Evolution of the thickness of the oxide film $d$ estimated from EIS measurements as a function of the potential - 304L SS - $\mathrm{HNO}_{3} 4 \mathrm{~mol} / \mathrm{L}-100^{\circ} \mathrm{C}$ - steady state

\section{Conclusion}

The oxidation behavior of AISI 304L SS has been investigated as a function of the potential in representative conditions of spent nuclear fuel dissolution in nitric acid $\left(\mathrm{HNO}_{3} 4 \mathrm{~mol} / \mathrm{L}\right.$ at $\left.100^{\circ} \mathrm{C}\right)$. In order to quantify the oxidation kinetics independently of the reduction kinetics, chronoamperometry experiments have been combined with mass loss measurements. A specific attention has been paid to characterize the system at steady-state by performing long term experiments.

The passive domain of the SS was evidenced, characterized by a slow and non-selective dissolution of the SS. This slow dissolution was explained by the presence of an oxide layer, relatively rich in chromium (valence III) and the thickness of which increases with potential. Interestingly accumulation of metallic nickel was observed under the oxide layer. 
At higher potential, the transpassive behavior was evidenced, characterized by a high mass loss rate and a specific intergranular corrosion morphology. It was shown that the total mass loss was due both to SS dissolution and grain dropping.

\section{Acknowledgments}

The authors thank AREVA NC and CEA for supporting these studies. We are also grateful to H. Badji and M. Tabarant for ICP-AES analyses, F. Balbaud-Célérier, N. Brijou-Mokrani, P. Fauvet, B. Fieulaine, O. Genève, N. Gruet, P. Laghoutaris, D. Mas, and R. Robin for their helpful suggestions and assistances during this study. 


\section{References}

[1] P.D. Wilson, The Nuclear Fuel Cycle: From Ore to Waste, Oxford Science Publications, 1997.

[2] P. Fauvet, Corrosion issues in nuclear fuel reprocessing plants, in: D. Feron (Ed.) Nuclear corrosion science and engineering, Woodhead Publishing, 2012, pp. 679-728.

[3] M. Pourbaix, Atlas d'équilibres électrochimiques, Gauthier, villars \& Cie, 1963.

[4] D.D. Macdonald, On the Existence of Our Metals-Based Civilization, Journal of The Electrochemical Society, 153 (2006) B213.

[5] R. Robin, F. Miserque, V. Spagnol, Correlation between composition of passive layer and corrosion behavior of high Si-containing austenitic stainless steels in nitric acid, J. Nucl. Mater., 375 (2008) 65-71.

[6] N. Padhy, R. Paul, U. Kamachi Mudali, B. Raj, Morphological and compositional analysis of passive film on austenitic stainless steel in nitric acid medium, Applied Surface Science, 257 (2011) 5088-5097.

[7] H. Kajimura, N. Usuki, H. Nagano, Dual layer corrosion protective film formed on Si bearing austenitic stainless steel in highly oxidizing nitric acid, in: Proceedings of the Symposium on Passivity and Its Breakdown, 1998, pp. 332-343.

[8] P. Fauvet, F. Balbaud, R. Robin, Q.T. Tran, A. Mugnier, D. Espinoux, Corrosion mechanisms of austenitic stainless steels in nitric media used in reprocessing plants, J. Nucl. Mater., 375 (2008) 52-64.

[9] F. Ueno, C. Kato, T. Motooka, S. Ichikawa, M. Yamamoto, Intergranular corrosion mechanism of ultra-low carbon type 304 stainless steel in a nuclear reprocessing plant, in: Global 2007, Boise, Idaho, 2007, pp. 1389-1393.

[10] L. Beaunier, Modèle théorique de la dissolution sélective aux joints de grains. Application à la corrosion intergranulaire., in: $\mathrm{PhD}$, Université Pierre et Marie Curie Paris 6, 1976.

[11] L. Beaunier, Corrosion of grain boundaries : initiation processes and testing, Journal de Physique, Colloque C6, supplement to Journal de Physique $n^{\circ} 12$ (1982) C6-271 C276-282.

[12] L. Beaunier, M. Froment, C. Vignaud, A kinetical model for the electrochemical grooving of grain boundaries, Electrochimica Acta, 25 (1980) 1239-1246.

[13] B. Gwinner, M. Auroy, V. Bague, Corrosion intergranulaire dans l'acide nitrique des aciers inoxydables austénitiques non sensibilités, Revue de métallurgie, 107 (2010) 441443.

[14] V. Bague, S. Chachoua, Q.T. Tran, P. Fauvet, Determination of the long-term intergranular corrosion rate of stainless steel in concentrated nitric acid, J. Nucl. Mater., 392 (2009) 396-404.

[15] J.-P. Schosger, Contribution à la connaissance du comportement de l'acier Z3 CN 18-10 dans l'acide nitrique concentré, chaud et confiné., in: $\mathrm{PhD}$, Institut National Polytechnique de Toulouse, 1996.

[16] F. Balbaud, Mécanisme de corrosion de l'acier inoxydable Z3 CN 18.10 en présence de condensats nitriques, in: $\mathrm{PhD}$, Université Pierre et Marie Curie, Paris, 1998.

[17] D. Sicsic, Modélisation thermodynamique et cinétique de la réduction de l'acide nitrique concentrée, in: $\mathrm{PhD}$, Université Pierre et Marie Curie, 2011.

[18] R. Lange, Phénomènes de couplage acier 304L - platinoïdes dans les milieux de dissolution des combustibles usés, in: PhD, Université Pierre et Marie Curie, 2012.

[19] D. Sicsic, F. Balbaud-Celerier, B. Tribollet, Mechanism of Nitric Acid Reduction and Kinetic Modelling, Eur. J. Inorg. Chem., (2014) 6174-6184. 
[20] G.O.H. Whillock, S.E. Worthington, J.A.R. Tony, Corrosion in nitric acid, in: Shreir's Corrosion, Elsevier, Oxford, 2010, pp. 1250.

[21] B. Raj, U.K. Mudali, Materials development and corrosion problems in nuclear fuel reprocessing plants, Prog. Nucl. Energy, 48 (2006) 283-313.

[22] F. Balbaud, G. Sanchez, G. Santarini, G. Picard, Cathodic reactions involved in corrosion processes occurring in concentrated nitric acid at 100 degrees C, Eur. J. Inorg. Chem., (2000) 665-674.

[23] R. Lange, E. Maisonhaute, R. Robin, V. Vivier, On the kinetics of the nitrate reduction in concentrated nitric acid, Electrochemistry Communications, 29 (2013) 2528.

[24] K. Vetter, Uber den enstellungsmechanismus des HNO2/HNO3 redoxpotentials, Z.Phys.Chem., 194 (1950) 199-206.

[25] K. Vetter, Die Abhängigkeit der Anfangsneigung der Stromdichte-Potentialkurve von den Konzentrationen,Rückschlüsse auf den potentilbestimmenden Vorgang bei Redoxsystemen, Z.Phys.Chem., 194 (1950) 284-296.

[26] K.J. Vetter, Entgegnung auf die vorstehende Arbeit von G.Schmid über «Die autokatalytische Natur der kathodischen Reduktion von Salpetersäure zu salpetriger Säure », Zeitschrift für Elektrochemie, 63 (1959) 1189-1191.

[27] G. Schmid, Die autokatalytische Natur de kathodischen Reduktion von Salpetersäure zu salpetriger Säure. I.Zur Deutung stationärer Strom-Spannungs-Kurven, Zeitschrift für Elektrochemie, 63 (1959) 1183-1188.

[28] G. Schmid, Die autokatalytische Natur der kathodischen Reduktion von Salpetersäure zu salpetriger Säure. III.Mathematische Behandlung einer autokatalytischen Elektrodenreaktion 1.Ordnung, Zeitschrift für Elektrochemie, 65 (1961) 531-534.

[29] G. Schmid, Die autokatalytische Natur der kathodischen Reduktion von Salpetersäure zu salpetri $\neg$ ger Säure. IV. Der potentiostatische Einschaltvorgang, Ber. Bunsengesellschaft physik Chem, 68 (1964) 677-688.

[30] G. Schmid, Das Verhalten von salpetriger und Salpetersäure an der rotierenden Scheibenelektrode. I. HNO2 in schwefelsauren Lösungen ohne HNO3-Zusatz, Berichte der Bunsengesellschaft, 73 (1969) 189-199.

[31] G. Schmid, J. Delfs, Die autokatalytische Natur der kathodischen Reduktion von Salpetersäure zu salpetriger Säure. II.Der galvanostatische Einschaltvorgang, Zeitschrift für Elektrochemie, 63 (1959).

[32] V.P. Razygraev, Certain characteristics of the cathodic reduction of nitric acid on a platinum electrode, Doklady Akademii nauk SSSR, 288 (1986) 1428-1432.

[33] V.P. Razygraev, M.V. Lebedeva, S.A. Kabakchi, E.Y. Ponomareva, R.S. Balovneva, L.P. Lobanova, Features Of Cathode Reduction Of Boiling Solutions Of Nitric-Acid On A Platinum-Electrode, Journal Of Applied Chemistry Of The Ussr, 61 (1988) 67-73.

[34] P. Marcus, V. Maurice, Comparison of atomic structures of passive films on chromium and on ferritic and austenitic stainless steels, in: P.M. Natishan, H.S. Isaacs, M. JanikCzachor, V.A. Macagno, P. Marcus, M. Seo (Eds.) Proceedings of the Symposium on Passivity and Its Breakdown, Electrochemical Society Inc, Pennington, 1998, pp. 254-265.

[35] I. Annergren, M. Keddam, H. Takenouti, D. Thierry, Application of electrochemical impedance spectroscopy and rotating-ring disc measurements on $\mathrm{Fe}-\mathrm{Cr}$ alloys, Electrochimica Acta, 38 (1993) 763-771.

[36] N. Hara, Sugimoto, K., In situ analysis of passive films on Fe-Cr-Ni alloy by potential-modulated UV-visible reflection spectroscopy, Journal of Electrochemical Society, 138 (1991) 1594. 
[37] S. Haupt, H.H. Strehblow, A combined surface analytical and electrochemical study of the formation of passive layers on $\mathrm{Fe} / \mathrm{Cr}$ alloys in $0.5 \mathrm{M} \mathrm{H} 2 \mathrm{SO} 4$, Corrosion Science, 37 (1995) 43-54.

[38] N. Hara, Sugimoto, K., Properties of high purity Fe-Cr alloy, in, 1995, pp. 84.

[39] S. Haupt, H.H. Strehblow, Combined electrochemical and surface analytical investigations of the formation of passive layers, Corrosion Science, 29 (1989) 163-182.

[40] S.H.-H. Calinski C., ISS depth profiles of the passive layer on $\mathrm{Fe} / \mathrm{Cr}$ Alloys, J. Electrochem. Soc., 136 (1989) 1328 - 1331.

[41] P. Marcus, J.M. Grimal, The anodic dissolution and passivation of Ni---Cr---Fe alloys studied by ESCA, Corrosion Science, 33 (1992) 805.

[42] D. Landolt, Passivité des métaux, in: D. Landolt (Ed.) Corrosion et chimie de surface des métaux, 1993, pp. 207-249.

[43] N. Sato, Present state of understanding of metallic passivity, in: The first japanUSSR corrosion seminar in Moscow on december 5-14, 1977, pp. 195-227.

[44] H.H. Strehblow, The investigation of passive layers with XPS and ISS, in: Proceeding of the corrosion et prevention'97 Conférence, Australia, 1997, pp. 1-9.

[45] C.O.A. Olsson, D. Landolt, Passive films on stainless steels--chemistry, structure and growth, Electrochimica Acta, 48 (2003) 1093-1104.

[46] X. Guo, H. Imaizumi, K. Katoh, The behaviour of passive films on carbon steel in sulfuric acid solutions, Journal of Electroanalytical Chemistry, 383 (1995) 99-104.

[47] B. Hirschorn, M.E. Orazem, B. Tribollet, V. Vivier, I. Frateur, M. Musiani, Determination of effective capacitance and film thickness from constant-phase-element parameters, Electrochimica Acta, 55 (2010) 6218-6227.

[48] K. Osozawa, H.J. Engell, The anodic polarization curves of iron-nickel-chromium alloys, Corrosion Science, 6 (1966) 389.

[49] J.C. Charbonnier, P. Maitrepierre, P. Noual, T. Namdar Irani, Study of passive layers on Mo-bearing ferritic stainless steels by auger electron and secondary ion mass spectroscopies, in: Proc. 7th Intern. Vac. Congr. \& 3rd Intern. Conf. Solid Surfaces (Vienna 77), 1977, pp. 2375-2378.

[50] P.N. Marimuthu, A.P. Kabilan, Corrosion estimation of stainless steel in nitric acid by an optoelectronic instrument based on diffuse light scattering pattern measurement, IEEE Sens. J., 10 (2010) 1658-1665.

[51] S. Ningshen, U. Kamachi Mudali, S. Ramya, B. Raj, Corrosion behaviour of AISI type 304L stainless steel in nitric acid media containing oxidizing species, Corrosion Science, 53 (2011) 64-70.

[52] S. Ningshen, U.K. Mudali, G. Amarendra, B. Rai, Corrosion assessment of nitric acid grade austenitic stainless steels, Corrosion Science, 51 (2009) 322-329.

[53] N. Padhy, S. Ningshen, U. Kamachi Mudali, B. Raj, In situ surface investigation of austenitic stainless steel in nitric acid medium using electrochemical atomic force microscopy, Scripta Materialia, 62 (2010) 45-48.

[54] R. Priya, S. Ningshen, U.K. Mudali, Influence of oxidizing ion concentration on the corrosion resistance of type 304L stainless steel in nitric acid medium, Corrosion, 69 (2012) 335-344.

[55] G. Suresh, V.R. Raju, U.K. Mudali, R.K. Dayal, Corrosion assessment of type 304L stainless steel in nitric acid, Corrosion Engineering Science and Technology, 38 (2003) 309-312.

[56] S. Haupt, H.H. Strehblow, The formation of the passive layer on $\mathrm{Cr}$ in $0.5 \mathrm{M} \mathrm{H} 2 \mathrm{SO} 4$ A combined electrochemical and surface analytical study, Journal of Electroanalytical Chemistry, 228 (1987) 365. 
[57] T. Shibata, G. Okamoto, Effect of the potential of etching treatment and passivation treatment on the stability of the passive stainless steels, Boshoku Gijutsu, 21 (1972) 263.

[58] M. Bojinov, G. Fabricius, T. Laitinen, T. Saario, G. Sundholm, Conduction mechanism of the anodic film on chromium in acidic sulphate solutions, Electrochimica Acta, 44 (1998) 247.

[59] A. Joshi, D.F. Stein, Chemistry of grain-boundaries and its relation to intergranular corrosion of austenitic stainless-steel, Corrosion, 28 (1972) 321-330.

[60] M. Froment, Sur le mécanisme de la corrosion intergranulaire des matériaux métalliques, J. Phys. Colloques, 36 (1975) C4-371-C374-385.

[61] O.V. Kasparova, S.D. Bogolyubskii, Y.M. Kolotyrkin, V.M. Milman, Improving the resistance of austenitic stainless-steels to intercrystalline corrosion in strongly oxidizing media by regulating their impurity content, Protection of Metals, 20 (1984) 635-640.

[62] K.T. Aust, G. Palumbo, Environmental interactions at grain boundaries, in: Fourth Japan Institut of Metals International Symposium, 1986, pp. 995-1004.

[63] S. Abe, M. Kaneko, H. Komatsu, F. Kurosawa, The compound dependent intergranular corrosion mechanism in stainless-steels, Tetsu to Hagane-Journal of the Iron And Steel Institute of Japan, 79 (1993) 713-720.

[64] O.V. Kasparova, S.D. Bogolyubskii, Y.M. Kolotyrkin, E.A. Ulyanin, A.B. Vasyukov, N.S. Yudina, S.V. Kostromina, Influence of the impurities phosphorus, sulfur, and molybdenum on the corrosion-electrochemical behavior of steel Kh20n20 in acidmedia in the transpassivation region, Protection of Metals, 15 (1979) 115-121.

[65] O.V. Kasparova, Y.M. Kolotyrkin, V.M. Milman, Y.B. Skuratnik, M.A. Dembrovskii, E.N. Lubnin, Influence of phosphorus on the Corrosion and electrochemical-behavior of steel Kh20n20 in sulfuric-acid, Protection of Metals, 20 (1984) 409-414.

[66] F. Ueno, A. Komatsu, T. Igarashi, M. Yamamoto, Study on the effect of phosphorous concentration on intergranular corrosion of stainless steel in boiling nitric acid solution, in: Eurocorr, Pise (Italie), 2014.

[67] J.S. Armijo, Intergranular corrosion of nonsensitized austenitic stainless steels, Corrosion, 24 (1968) 24-30.

[68] O.V. Kasparova, V. Cihal, V.M. Milman, I. Kasova, S.D. Bogolyubskii, N.M. Ostrikova, Study of the corrosion and electrochemical-behavior in nitric-acid media of steel-Kh20n20 with different contents of phosphorus and silicon, Protection of Metals, 27 (1991) 554-562.

[69] H. Nagano, Stainless-steel corrosion in concentrated nitric acid, Corrosion engineering, 37 (1988) 263-274.

[70] R.W. Staehle, Corrosion problems and corrosion monitoring in nitric acid reprocessing environments, in, 1996.

[71] D.A. Vermilyea, J. Tedmon, C.S., D.E. Broecker, Effect of phosphorus and silicon on the intergranular corrosion of a nickel-base alloy, Corrosion - NACE, (1974) 222-223.

[72] Y. Watanabe, R.G. Ballinger, O.K. Harling, G.E. Kohse, Effects of neutronirradiation on transpassive corrosion behavior of austenitic stainless-steels, Corrosion, 51 (1995) 651-659.

[73] H. Kajimura, The effects of $\mathrm{Cr}$ and $\mathrm{P}$ on the corrosion behavior of stainless steels in nitric acid containing oxidizing ions, Corrosion Engineering, 41 (1992) 15-28.

[74] A. Desestret, J. Ferriol, G. Vallier, Cas d'application de deux aciers inoxydables spéciaux dans les usines de traitement des combustibles nucléaires. Discution on two special stainless steels used in nuclear fuel processing plants. Corrosion des aciers inoxydables des types $\mathrm{Cr} 18-\mathrm{Ni} 10$ ou $\mathrm{Cr} 25-\mathrm{Ni} 20$ dans les milieux acides oxydants ou très oxydants - choix d'un acier, Matériaux et techniques, (1977) 3-18 and 11-16. 
[75] A. Camus, Desestre.A, M. Froment, Guiralde.P, Influence du silicium sur la corrosion intergranulaire et l'énergie des joints de grains d'aciers inoxydables austénitiques nickel chrome, Comptes Rendus Hebdomadaires Des Seances De L Academie Des Sciences Serie C, 264 (1967) 425-428.

[76] H. Coriou, Aciers inoxydables avec addition de silicium : étude générale de leur comportement dans les milieux acides très oxydants, Revue de métallurgie, (1965) 11931203.

[77] H. Coriou, Corrosion intergranulaire des aciers inoxydables austénitiques dans les milieux acides très oxydants, Corrosion et anticorrosion, 14 (1966) 163-170.

[78] H. Coriou, A. Desestret, L. Grall, J. Hochmann, Corrosion intergranulaire des aciers inoxydables austénitiques dans les milieux acides très oxydants. Influence de la teneur en silicium de l'acier, Mémoires Scientifiques Rev. Metallurg., LXI (1964) 177-183.

[79] A. Desestret, M. Froment, P. Guiraldenq, Application des radioéléments à l'étude de l'influence du silicium sur quelques propriétés des joints de grains d'aciers inoxydables austénitiques, Mém. Sci. Rev. Métall. (F), 66 (1969) 389-405.

[80] B. Ghiban, Structural aspects of the intergranular corrosion resistance of some silicon alloyed austenitic stainless steel, Rastermikrosk materialpruef vortr tag, (1996) 255-262.

[81] B. Ghiban, Silicon influence on corrosion properties of austenitic stainless steels, in: I. Chicinas, T. Canta (Eds.) Materials and Technologies, Trans Tech Publications Ltd, Stafa-Zurich, 2007, pp. 261-264.

[82] B. Ghiban, S. Ciuca, I. Carceanu, N. Ghiban, I. Nedelcu, Austenitic stainless steels corrosion properties modified by silicon alloying, Metal. Int., 13 (2008) 39-42.

[83] B. Ghiban, G. Cosmeleata, Properties of a silicon austenitic stainless steel for resistance in agressive media, in: Innovation stainless steel, eur.stainless steel conf.,1st (1993), associazione italiana di metallurgia, milan, italie, 1993, pp. 183-188.

[84] B. Ghiban, E. Dragulanescu, N. Ghiban, Kinetics of electrochemical corrosion processes of silicium-austenitic stainless steels, Metalurgia, 51 (1999) 123-133.

[85] B. Ghiban, N. Ghiban, Silicon influence on corrosion behaviour of stainless steels, University "Politehnica" of Bucharest, Scientific Bulletin Series B: Chemistry and Materials Science|University "Politehnica" of Bucharest, Scientific Bulletin Series B: Chemistry and Materials Science, 62 (2000) 79-86.

[86] T. Honda, T. Yokosuka, Y. Arai, M. Sukekawa, Effet of silicon on intergranular corrosion of stainless steel in nitric solutions, in: Corrosion / 97, New Orleans, LA, US, 1997.

[87] O.V. Kasparova, Peculiarities of Intergranular Corrosion of Silicon-Containing Austenitic Stainless Steels, Protection of Metals, 40 (2004) 425.

[88] O.V. Kasparova, Y.V. Baldokhin, The effect of silicon on electron structure and corrosion-electrochemical behavior of a X20H20 type phosphorus-containing steel, Protection of Metals, 38 (2002) 408.

[89] O.V. Kasparova, Y.V. Baldokhin, G.A. Kochetov, The effect of silicon on the electronic structure and corrosion-electrochemical behavior of austenitic steels, Protection of Metals, 38 (2002) 176.

[90] J. Stolarz, J. Le Coze, Intergranular corrosion of stainless steels under transpassive conditions : study of silicon segregation in $<001>$ tilt bicrystals, Colloque de physique, Colloque C1, supplément au nº1 (1990) C1-641 - C1645.

[91] J. Stolarz, Influence of silicon, carbon and phosphorus on intergranular corrosion of high purity austenitic stainless steels under transpassive conditions, Journal de Physique IV, 5 (1995) C7-423-C427-428. 
[92] D.N. Wasnik, V. Kain, I. Samajdar, B. Verlinden, P.K. De, Resistance to sensitization and intergranular corrosion through extreme randomization of grain boundaries, Acta Materialia, 50 (2002) 4587-4601.

[93] Y. Wang, J. Kaneda, S. Kasahara, N. Shigenaka, Improvement of corrosion resistance in austenitic stainless steel by grain boundary character distribution control, Corrosion Engineering, 61 (2012) 251-259.

[94] M.C. Biesinger, C. Brown, J.R. Mycroft, R.D. Davidson, N.S. McIntyre, X-Ray photoelectron spectroscopy studies of chromium compounds, Surface and Interface Analysis, 36 (2004) 1550-1563.

[95] L. Marchetti-Sillans, Corrosion généralisée des alliages à base nickel en milieu aqueux à haute température : Apport à la compréhension des mécanismes, in: $\mathrm{PhD}$, Ecole Nationale Supérieure des Mines de Saint-Etienne, 2007.

[96] R. Gupta, S.K. Sen, Calculation of multiplet structure of core p-vacancy levels, Physical ReviewB, 10 (1974) 6.

[97] R. Gupta, S.K. Sen, Calculation of multiplet structure of core p-vacancy levels II, Physical ReviewB, 12 (1975) 4.

[98] X.Q. Li, J.S. Cao, W.X. Zhang, Stoichiometry of $\mathrm{Cr}(\mathrm{VI})$ immobilization using nanoscale zerovalent iron (nZVI): A study with high-resolution X-ray photoelectron Spectroscopy (HR-XPS), Industrial \& Engineering Chemistry Research, 47 (2008) 21312139.

[99] K. Ogle, M. Mokaddem, P. Volovitch, Atomic emission spectroelectrochemistry applied to dealloying phenomena II. Selective dissolution of iron and chromium during active-passive cycles of an austenitic stainless steel, Electrochimica Acta, 55 (2010) 913921.

[100] S. Marcelin, N. Pebere, S. Regnier, Electrochemical characterisation of a martensitic stainless steel in a neutral chloride solution, Electrochimica Acta, 87 (2013) 32-40.

[101] M.G.S. Ferreira, M.D. Belo, N.E. Hakiki, G. Goodlet, M.F. Montemor, A.M.P. Simoes, Semiconducting properties of oxide and passive films formed on AISI 304 stainless steel and Alloy 600, Journal of the Brazilian Chemical Society, 13 (2002) 433440.

[102] A.J. Bard, Electrochimie : principes, méthodes et applications., Masson ed., 1983. 